\title{
Bibliografía sobre investigaciones marinas, oceanográficas, geológicas y atmosféricas en el Parque Nacional Isla del Coco y aguas adyacentes, Pacífico de Costa Rica
}

\section{Jorge Cortés}

Centro de Investigación en Ciencias del Mar y Limnología (CIMAR), Ciudad de la Investigación, Universidad de Costa Rica, San Pedro, 11501-2060 San José, Costa Rica; jorge.cortes@ucr.ac.cr

\author{
Recibido 31-I-2012. Corregido 30-VII-2012. Aceptado 24-IX-2012.
}

\begin{abstract}
Bibliography on marine, oceanographic, geological and atmospheric research at Isla del Coco Nacional Park and adjacent waters, Pacific Costa Rica. Isla del Coco (also known as Cocos Island), Pacific Costa Rica, has been visited and written about since the 16th Century, and since the late 1800's many expeditions and scientists have carried out research in the Island. Here I compiled publications on marine biological, geological, oceanographic and atmospheric research done at Isla del Coco. A list of 599 scientific papers and chapters were compiled, together with 41 books, reports, Special Issues, theses and web sites, and ten historic books with descriptions of marine animals or environemnets. A mayority of the publications (425 or $66.4 \%$ ) are related to marine biodiversity topics (species descriptions and lists of species); the most published groups are gastropods (81 papers), decapods (67) and bony fishes (66). There are no publications of several groups of animals that have been observed in the Island, for example free-living flat worms, parasites and nemerteans among others. Other topics with a large number of publications are, biogeography with 65, ecology (61) and geology (48); the most studied ecosystem are coral reefs with 14 papers. More publications are needed on many topics, such as impact of ilegal fishing and climate change on Isla del Coco National Park marine flora and fauna. Citation: Cortés, J. 2012. Bibliografía sobre investigaciones marinas, oceanográficas, geológicas y atmosféricas en el Parque Nacional Isla del Coco y aguas adyacentes, Pacífico Costa Rica. Rev. Biol. Trop. 60 (Suppl. 3): 363-392. Epub 2012 Dec 01.
\end{abstract}

Key words: Parque Nacional Isla del Coco, Cocos Island, Costa Rica, bibliography, biodiversity, marine ecosystems, atmospheric science, physical oceanography, chemical oceanography, geology.

Sobre la Isla del Coco se han publicado muchos trabajos desde hace varios siglos (Montoya 2007, ver referencias de libros históricos al final) y desde finales del Siglo XIX ha habido una gran cantidad de expediciones e investigaciones en el área marina de la Isla (Cortés 2008). Mucha de esta literatura es de difícil acceso y en algunos casos hasta desconocida por muchos científicos. El objetivo de este trabajo es recopilar las publicaciones científicas sobre investigaciones marinas, geológicas, oceanográficas y atmosféricas desarrolladas en el Parque Nacional Isla del Coco y aguas adyacentes, Pacífico de Costa Rica. Se presentan los resultados de análisis sobre las áreas de investigación, los grupos marinos y ecosistemas marinos más estudiados. Se espera que esta recopilación sirva de base y motivación para impulsar las investigaciones científicas en esa región y en el resto de Pacífico Tropical Oriental.

La lista de publicaciones incluye 599 referencias de artículos científicos y capítulos en libros, más, 41 tesis, libros, volúmenes especiales, memorias de reuniones, informes sobre investigaciones marinas, oceanográficas, geológicas y atmosféricas y un sitio web, y diez libros históricos en los que se mencionan aorganismos y ambientes marinos de la Isla del Coco. El área de investigación del cual 
hay más publicaciones es sobre biodiversidad (taxonomía, listas de especies), con 425 trabajos $(66.4 \%)$, de los cuales, de los gasterópodos es de los que hay más publicaciones (81) seguido por los crustáceos decápodos con 67 y peces óseos con 66 (Cuadro 1). No hay publicaciones sobre algunos grupos aunque han sido observados en el Parque Nacional Isla del Coco, por ejemplo, gusanos planos de vida libre, nemertinos y parásitos (Cortés 2012). En cuanto a temas del que más publicaciones hay es biogeografía (65 publicaciones), seguido por ecología con 61 y geología con 48 (aunque solamente hay un trabajo de la geología general de la Isla del Coco: Rojas \& Alvarado 2012). El ecosistema más estudido ha sido los arrecifes. Del tema de las actividades socio-económico relacionado con los organismos y ambientes marinos hay una publicación reciente (MorenoDíaz 2012), pero hacen falta más estudios.

Aunque la mayoría de las publicaciones son sobre biodiversidad marina, todavía falta mucho por conocer y en especial sobre la historia natural y estatus de las poblaciones de esas especies. Se necesita desarrollar más trabajos sobre la oceanografía física y química del Parque como también sobre el plancton. Finalmente, no hay un solo estudio sobre el impacto de la pesca alrededor del Parque o sobre la pesca ilegal dentro del Parque (actividad que afortunamente es poca, pero existe). También faltan trabajos sobre el posible impacto del turismo y del cambio climático sobre los organismos y ambientes marinos del Parque Nacional Isla del Coco.

\section{AGRADECIMIENTO}

Le agradezco profundamente a Kay Hale, Exdirectora de la Biblioteca de la Rosenstiel School of Marine and Atmospheric Science (RSMAS) de la Universidad de Miami, todas las copias de publicaciones que me ha enviado y sigue enviando. Igualmente agradezco a Michel Montoya la gran ayuda dada, A Harlan Dean por las publicaciones del Museo de Zoología Comparada en la Universidad de Harvard, a Guillermo Alvarado por las publicaciones geológicas y a Eric Alfaro por las de ciencias atmosféricas. Le agradezco la revisión de la lista y el envío de artículos adicionales a Eric Alfaro, Guillermo Alvarado, Juan José Alvarado, Odalisca Breedy, Richard Brusca, Harlan Dean, Cindy Fernández, Ginger Garisson, Astrid Sánchez, Rita Vargas, Benjamin Victor e Ilena Zanella. Esta compilación se realizó mientras desarrollaba proyectos de investigación sobre el Parque Nacional Isla del Coco, Área de Conservación Marina Isla del Coco (ACMIC) y conté con apoyo de la Vicerrectoría de Investigación y del CIMAR de la Universidad de Costa Rica, del Fonds Français pour l'Environnement Mondial (FFEM) y del Consejo Nacional de Rectores de las Universidades Públicas de Costa Rica (CONARE).

\section{RESUMEN}

Isla del Coco, Pacífico de Costa Rica, ha sido visitada y se ha escrito sobre ella desde el Siglo XVI. Desde finales del Siglo XIX muchas expediciones han desarrollado investigaciones en el Isla. Aquí compilo las publicaciones sobre biología y geología marina, oceanografía física y química, ciencias atmosféricas y algunos temas sociales. Una lista de 599 artículos y capítulos, 41 libros, Suplementos, tesis, informes y un sitio de internet es incluida, y diez libros históricos donde se describen organismos y ambientes marinos de la Isla del Coco. La mayoría de las publicaciones $(425$ o $66.4 \%$ ) son sobre biodiversidad marina (descripciones, listas y distribuciones de especies). De los grupos que más publicaciones hay son de los gasterópodos (81 trabajos), decápodos (67) y peces óseos (66). No hay publicaciones de varios grupos de animales que han sido observados en Isla del Coco, por ejemplo, gusanos planos de vida libre, parásitos o nemertinos, entre otros. Temas con muchas publicaciones son: biogeografía con 65, ecología (61) y geología (48); los ecosistemas más estudiados son los arrecifes coralinos con 14 trabajos. Se necesitan más publicaciones en muchos tópicos, tales como el impacto sobre la flora y fauna del Parque Nacional Isla del Coco de la pesca ilegal y el cambio climático.

Palabras claves: Parque Nacional Isla del Coco, Costa Rica, bibliografía, biodiversidad, ecosistemas marinos, ciencias atmosféricas, oceanografía física, oceanografía química, geología. 
CUADRO 1

Número de publicaciones de cada tema y el código usado en la lista de referencias

TABLE 1

Number of publications by topic and the codes used in the references list

\begin{tabular}{|c|c|c|c|c|c|}
\hline Tema & \# Publ. & Tema & \# Publ. & Tema & \# Publ. \\
\hline $\mathrm{Al}=\mathrm{Algas}$ & 8 & $\mathrm{Cv}=$ Conservación & 14 & MS $=$ Montes Submarinos & 3 \\
\hline Ap $=$ Apendicularias & 1 & $\mathrm{CVC}=$ Cordillera Volcánica de Coco & 4 & $\mathrm{OF}=$ Oceanografía Física & 16 \\
\hline $\mathrm{Ar}=$ Arrecifes & 14 & DCR $=$ Domo de Costa Rica & 1 & $\mathrm{OQ}=$ Oceanografía Química & 3 \\
\hline$A v=$ Aves & 23 & $\mathrm{Di}=$ Dinoflagelados & 1 & $\mathrm{Pc}=$ Picnogónido & 3 \\
\hline $\mathrm{Ba}=$ Braquiópodos & 4 & $\mathrm{DR}=$ Dataciones Radiométricas & 6 & $\mathrm{Pe}=$ Pesquería & 2 \\
\hline $\mathrm{Bb}=$ Bibliografía & 3 & $\mathrm{Ec}=$ Echinodermata & 14 & $\mathrm{Ph}=$ Forónidos & 1 \\
\hline $\mathrm{Bd}=$ Biodiversidad & 425 & $\mathrm{EcA}=$ Asteroideos, Echinodermata & 5 & $\mathrm{PiA}=$ Peces óseos & 66 \\
\hline $\mathrm{Be}=$ Bentos & 1 & EcE $=$ Equinoideos, Echinodermata & 14 & $\mathrm{PiE}=$ Peces cartilaginosos & 41 \\
\hline $\mathrm{Bg}=$ Biogeografía & 65 & $\mathrm{EcH}=$ Holoturoideos, Echinodermata & 5 & $\mathrm{PIF}=$ Fitoplancton & 2 \\
\hline $\mathrm{Bi}=$ Bioerosión & 2 & $\mathrm{EcO}=$ Ofiuroideos, Echinodermata & 5 & $\mathrm{PlZ}=$ Zooplancton & 5 \\
\hline $\mathrm{Br}=$ Briozoarios & 6 & Eg = Ecología & 61 & Po $=$ Esponjas & 4 \\
\hline $\mathrm{B} \& \mathrm{~A}=$ Bacterias y Arquea & 1 & ENOS = El Niño-Oscilación del Sur & 5 & $\mathrm{PP}=$ Productividad Primaria & 1 \\
\hline $\mathrm{CA}=$ Ciencias Atmosféricas & 14 & Ep $=$ Expediciones & 29 & $\mathrm{PpC}=$ Parásitos peces, Copépodos & 1 \\
\hline $\mathrm{CC}=$ Cambio Climático & 4 & $\mathrm{Er}=$ Echiúridos & 2 & Py $=$ Polychaeta & 10 \\
\hline $\mathrm{Ce}=$ Cefalocordados & 1 & Ev = Evolución & 9 & $\mathrm{Qt}=$ Quetognatos & 2 \\
\hline $\mathrm{Cm}=$ Comportamiento & 8 & $F_{0}=$ Foraminíferos & 6 & Ro $=$ Rodolitos & 1 \\
\hline $\mathrm{Cn}=$ Cnidaria & 5 & $\mathrm{Ge}=$ Geología & 48 & $\mathrm{Rp}=$ Reptiles & 5 \\
\hline $\mathrm{CnA}=$ Antozoarios, Cnidaria & 24 & $\mathrm{Gg}=$ Geografía & 1 & $\mathrm{Sa}=$ Salpas & 1 \\
\hline $\mathrm{CnH}=$ Hydrozoarios, Cnidaria & 10 & $\mathrm{Gn}=$ Genética & 11 & $\mathrm{Sd}=$ Sedimentos & 2 \\
\hline $\mathrm{CnM}=$ Medusas, Cnidaria & 4 & Go $=$ Geomorfología & 7 & $\mathrm{SE}=$ Estudios socio-económicos & 1 \\
\hline $\mathrm{Co}=$ Colecciones $/$ museos & 1 & $\mathrm{Hi}=$ Historia & 26 & $\mathrm{Si}=$ Sipuncúlidos & 3 \\
\hline $\mathrm{Cr}=$ Crustacea & 6 & $\mathrm{IM}=$ Insectos Marinos & 2 & $\mathrm{Sm}=$ Simposio & 2 \\
\hline $\mathrm{CrA}=$ Anfípodos, Crustacea & 9 & $\operatorname{Inf}=$ Informes & 7 & $\mathrm{Te}=$ Tesis & 7 \\
\hline $\mathrm{CrC}=$ Copépodos, Crustacea & 3 & $\mathrm{Li}=\mathrm{Libros}$ & 20 & $\mathrm{TP}=$ Tectónica de placas & 20 \\
\hline $\mathrm{CrD}=$ Decápodos, Crustacea & 67 & $\mathrm{Lg}=$ Legislación & 2 & $\mathrm{Tx}=$ Toxicidad & 1 \\
\hline $\mathrm{CrI}=$ Isópodos, Crustacea & 4 & $\mathrm{Mm}=$ Mamíferos marinos & 16 & $\mathrm{Vu}=$ Vulcanología & 17 \\
\hline CrM = Misidáceos, Crustacea & 1 & Mo $=$ Mollusca & 34 & $\mathrm{VC}=$ Variabilidad Climática & 4 \\
\hline $\mathrm{CrP}=$ Cirripedios, Crustacea & 4 & MoB = Bivalvos, Mollusca & 23 & $\mathrm{VE}=$ Volumen Especial/Suplemento & 2 \\
\hline $\mathrm{CrS}=$ Estomatópodos, Crustacea & 6 & MoC $=$ Cefalópodos, Mollusca & 7 & $\mathrm{Vi}=$ Virus & 1 \\
\hline $\mathrm{CrT}=$ Tanaidáceos, Crustacea & 2 & MoG = Gasterópodos, Mollusca & 81 & $\mathrm{ZP}=$ Zonas Profundas & 11 \\
\hline $\mathrm{CtP}=$ Contaminación, Petróleo & 1 & MoP = Quitones, Mollusca & 5 & $\mathrm{ZR}=$ Zonas Rocosas & 3 \\
\hline $\mathrm{CtR}=$ Cotaminación, Radionucléidos & 1 & $\mathrm{Mp}=$ Mapas & 5 & & \\
\hline
\end{tabular}




\section{LISTA DE PUBLICACIONES (LIST OF PUBLICATIONS)}

1. Abele, L.G. 1975. The macruran decapod crustacea of Malpelo Island. In J.B. Graham (ed.). The Biological Investigations of Malpelo Island, Colombia. Smithsonian Contrib. Zool. 176: 69-85. (Bd, CrD)

2. Abele, L.G. 1977. The taxonomic status of Sesarma festae Nobili, 1901, S. ophioderma Nobili, 1901, and S. biolleyi Rathbun, 1906 (Crustacea, Decapoda, Grapsidae) in the Eastern Pacific. Proc. Biol. Soc. Washington 89: 631-644. (Bd, CrD)

3. Abele, L.G. 1992. A review of the grapsid crab genus Sesarma (Crustacea: Decapoda: Grapsidae) in America, with the description of a new genus. Smithsonian Contr. Zool. 527: 1-60. (Bd, CrD)

4. Abele, L.G. \& W. Kim. 1984. Notes on the freshwater shrimps of Isla del Coco with description of Macrobrachium cocoense, new species. Proc. Biol. Soc. Washington 97: 951-960. (Bd, CrD)

5. Acevedo-Gutiérrez, A. 1994. First record of a sea lion, Zalophus californianus, at Isla del Coco, Costa Rica. Mar. Mamm. Sci. 10: 484-485. (Mm)

6. Acevedo-Gutiérrez, A. 1994. First records of occurrence and nesting of three bird species at Isla del Coco, Costa Rica. Rev. Biol. Trop. 42: 762. (Av, Eg)

7. Acevedo-Gutiérrez, A. 1996. Lista de mamíferos marinos en Golfo Dulce e Isla del Coco. Rev. Biol. Trop. 44: 933-934. (Bd, Mm)

8. Acevedo-Gutiérrez, A. 1999. Aerial behavior is not a social facilitator in bottlenose dolphins hunting in small groups. J. Mamm. 80: 768-776. (Cm, Eg, Mm)

9. Acevedo-Gutiérrez, A. 2002. Interactions between marine predators: dolphin food intake is related to number of sharks. Mar. Ecol. Prog. Ser. 240: 267-271. (Cm, Eg, Mm, PiE)

10. Acevedo-Gutiérrez, A. \& N. Parker. 2000. Surface behavior of bottlenose dolphins is related to spatial arrangement of prey. Mar. Mamm. Sci. 16: 287-298. (Cm, Eg, Mm)

11. Acevedo, A. \& M.A. Smultea. 1995. First records of humpback whales including calves at Golfo Dulce and Isla del Coco, Costa Rica, suggesting geographical overlap of northern and southern hemisphere populations. Mar. Mamm. Sci. 11: 554-560. (Eg, Mm)

12. Acevedo-Gutiérrez, A. \& S.C. Stienessen. 2004. Bottlenose dolphins (Tursiops truncatus) increase number of whistles when feeding. Aquat. Mamm. 30: 357-362. (Cm, Eg, Mm)

13. Acevedo, A. \& B. Würsig. 1991. Preliminary observations on bottlenose dolphins, Tursiops truncatus, at Isla del Coco, Costa Rica. Aquat. Mamm. 17: 148151. $(\mathrm{Cm}, \mathrm{Eg}, \mathrm{Mm})$
14. Acevedo-Gutiérrez, A., B. Brennan, P. Rodríguez \& M. Thomas. 1997. Resightings and behavior of false killer whales (Pseudorca crassidens) in Costa Rica. Mar. Mamm. Sci. 13: 307-314. (Cm, Eg, Mm)

15. Acuña, F.H., J. Cortés \& A. Garese. 2012. Ocurrence of the sea anemone Telmatactis panamensis (Verrill, 1869) (Cnidaria: Anthozoa: Actiniaria) at Isla del Coco National Park, Costa Rica. Rev. Biol. Trop. 60 (Suppl. 3): 201-205. (Bd, CnA)

16. Acuña, J., J. Cortés \& M. Murillo. 1996-1997. Mapa de sensibilidad ambiental para derrames de petróleo en las costas de Costa Rica. Rev. Biol. Trop. 44(3)/45(1): 463-470. (CtP, Mp)

17. Acuña-González, J., J. García-Céspedes, E. GómezRamírez, J.A. Vargas-Zamora \& J. Cortés. 2008. Parámetros físico-químicos en aguas costeras de la Isla del Coco, Costa Rica (2001-2007). Rev. Biol. Trop. 56 (Supl. 2): 49-56. (OQ)

18. Adamek, S., C. Frohlich \& W. Pennington. 1988. Seismicity of the Caribbean-Nazca boundary: constraints on microplate tectonics of the Panama region. J. Geophys. Res. 93: 2053-2075. (Ge, TP)

19. Agassiz, A. 1892. Reports on the dredging operations off the west coast of Central America to the Galápagos, to the west coast of Mexico, and in the Gulf of California, in charge of Alexander Agassiz, carried on by the U.S. Fish Commission Steamer "Albatross", Lieut. Commander Z.L. Tanner U.S.N., commanding. II. General sketch of the expedition of the "Albatross," from February to May, 1891. Bull. Mus. Comp. Zoöl. Harvard Coll. 23: 1-89. (Ep)

20. Agassiz, A. 1898. Reports on the dredging operations off the west coast of Central America to the Galápagos, to the west coast of Mexico, and in the Gulf of California, in charge of Alexander Agassiz, carried on by the U.S. Fish Commission Steamer "Albatross", Lieut. Commander Z.L. Tanner U.S.N., commanding. XXIII. Preliminary report on the echini. Bull. Mus. Comp. Zoöl. Harvard Coll. 32: 71-86. (Bd, EcE)

21. Agassiz, A. 1904. Reports on an exploration off the west coast of Mexico, Central and south America, and off the Galapagos Islands, in charge of Alexander Agassiz, by the U.S. Fish Commission Steamer "Albatross", during 1891, Lieut. Commander Z.L. Tanner, U.S. Commanding. XXXII. The Panamic deep sea echini. Mem. Mus. Comp. Zoöl. Harvard Coll. XXXI: 1-246. (Bd, EcE, ZP)

22. Alfaro, A. 1899. Flora y fauna de la Isla del Coco. Memoria Secretaría de Fomento, San José, Costa Rica 1899: 31-36. (Reimpreso en: Reproducciones científicas, una expedición y Legislación de la Isla del Coco. Instituto Geográfico Nacional (1964): 31-36.). (Bd, Ep) 
23. Alfaro, A. 1935. Informe sobre la fauna de la isla, 24 de junio de 1898. Rev. Col. Sup. Señoritas 4-5: 12-15. (Bd, Ep)

24. Alfaro, E.J. 2008. Ciclo diario y anual de variables troposféricas y oceánicas en la Isla del Coco, Costa Rica. Rev. Biol. Trop. 56 (Supl. 2): 19-29. (CA, VC)

25. Alfaro, E.J. \& F.J. Soley. 2009. Descripción de dos métodos de rellenado de datos ausentes en series de tiempo meteorológicas. Rev. Mate.: Teor. Aplic. 16: 59-74. (CA)

26. Allen, G.R. 2007. Conservation hotspots of biodiversity and endemisms for Indo-Pacific coral reef fishes. Aquat. Conserv. Mar Freshwat. Ecosyst. Publ. 18: 541-556. (Bg, Cv, PiA, PiE)

27. Allen, G.R. \& D.R. Robertson. 2002. Halichoeres salmofasciatus, a new species of wrasse (Labridae) from Isla del Coco, tropical eastern Pacific. Aqua 5: 65-72. (Bd, PiA)

28. Alvarado, G.E. 1982. Geomorfología y petrografía de algunas provincias volcánicas de Costa Rica. Bol. Vulc. 14: 25-28. (Ge, Go, Vu)

29. Alvarado, G.E. 1984. Distribución de las unidades litoestratigráficas ígneas del Neógeno y Cuaternario de Costa Rica. In P. Sprechmann (ed.). Manual de Geología de Costa Rica - Estratigrafía. Vol. 1: 301307. (Ge, $\mathrm{Vu})$

30. Alvarado, G.E. \& P.B. Gans. 2012. Síntesis geocronológica del magmatismo, metamorfismo y metalogenia de Costa Rica, América Central. Rev. Geol. Amér. Central 46: 7-122. (Ge, Vu)

31. Alvarado, G.E., S. Kussmaul, S. Chiesa, P.-Y. Gillot, G. Wörner \& C. Rundle. 1992. Cuadro cronoestratigráfico de las rocas ígneas de Costa Rica basado en dataciones radiométricas. J. South Amer. Earth Sci. 6: 151-168. (DR, Ge, Vu)

32. Alvarado, G.E., C. Sigarán \& W. Pérez. 2000. Vulcanismo: sus productos y geoformas, pp. 133-154. In P. Denyer \& S. Kussmaul (eds.). Geología de Costa Rica. Ed. Tecnol. Costa Rica, Cartago, Costa Rica. (Ge, Go)

33. Alvarado, J.J. 2010. Isla del Coco (Costa Rica) Echinoderms: state of knowledge, p. 103-113. In L.G. Harris, S.A. Böttger, C.W. Walker \& M.P. Lesser (eds.). Echinoderms: Durham. Proc. 12th Int. Echinoderm Conf. CRC Press, Taylor \& Francis Group, Balkema, Leiden, Netherlands. (Bd, Ec)

34. Alvarado, J.J. \& A. Chiriboga. 2008. Distribución y abundancia de equinodermos de las aguas someras en la Isla del Coco, Pacifico Oriental, Costa Rica. Rev. Biol. Trop. 56 (Supl. 2): 99-111. (Ec, Eg)

35. Alvarado, J.J. \& J. Cortés. 2004. The state of knowledge on echinoderms of Costa Rica and Central America, p. 149-155. In T. Heinzeller \& J.H.
Nebelsick (eds.), Echinoderms: München. Balkema Publ., Leiden. (Bd, Ec)

36. Alvarado, J.J. \& J. Cortés. 2009. Echinoderms. Texto: p. 421-433, Lista de especies, disco compacto: p. 392-408. In I.S. Wehrtmann \& J. Cortés (eds.). Marine Biodiversity of Costa Rica, Central America. Springer, Berlin. (Bd, Ec)

37. Alvarado, J.J., B. Herrera, L. Corrales, J. Asch, P. Paaby. 2011. Identificación de las prioridades de conservación de la biodiversidad marina y costera en Costa Rica. Rev. Biol. Trop. 59: 829-842. (Cv)

38. Alvarado, J.J., J. Cortés \& H. Reyes-Bonilla. 2012. Bioerosion impact model for the sea urchin Diadema mexicanum on three Costa Rican Pacific coral reefs. Rev. Biol. Trop. 60 (Supl. 2): 121-132. (Bi)

39. Alvarado, J.J., J. Cortés, M.F. Esquivel \& E. Salas. 2012. Costa Rica's Marine Protected Areas: review and perspectives. Rev. Biol. Trop. 60: 129-142. (Cv, Lg)

40. Alvarado J.J., E. Barraza \& T. Sancho-Mejía. 2013. Chapter 3: Central America Echinoderms: diversity, ecology and future perspectives, p. 67-106. In J.J. Alvarado \& F.A. Solís-Marín (eds.). Echinoderm Research and Diversity in Latin America. Springer, Berlin, Heidelberg. (Bd, Bg, Ec, Eg)

41. Alvarado-Quesada, G.M. 2006. Conservación de las aves acuáticas de Costa Rica. Brenesia 66: 49-68. (Av, Cv)

42. Alvariño, A. 1971. Siphonophores of the Pacific with a review of the world distribution. Bull. Scripps Inst. Oceanog. 16: 364 p. (Bd, CnH)

43. Amador, J. \& E. Alfaro. 2009. Métodos de reducción de escala: Aplicaciones al clima, variabilidad y cambio climático. REVIBEC 11: 39-52. (CA, VC)

44. Amador, J.A., E.J. Alfaro, O.G. Lizano \& V.O. Magaña. 2006. Atmospheric forcing of the eastern tropical Pacific: a review. Prog. Oceanogr. 69: 101-142. (CA)

45. Ancey, M.C.F. 1903. Faune malacologique terrestre de l'Ile des Cocos dans l'Océan Pacifique. J. Conchyl. 51: 97-104. (Bd, Mo)

46. Arauz, R. \& A. Antoniou. 2006. Preliminary results: movement of scalloped hammerhead shark (Sphyrna lewini) tagged in Cocos Island National Park, Costa Rica, 2005, p. 8-9. In R. Rojas \& I. Zanella (eds.). Memoria: Primer Seminario Taller sobre el estado del conocimiento de la Condrictiofauna de Costa Rica. INBio, Santo Domingo, Heredia, Costa Rica. (Eg, PiE)

47. Arauz, R., Y. Cohen, J. Ballestero, A. Bolaños \& M. Pérez. 2004. Decline of shark populations in the Exclusive Economic Zone of Costa Rica. Int. Symp. Mar. Biol. Indic. Fish. UNESCO, FAO, Paris, France. (Cv, PiE, Sm) 
48. Arauz, R., A. López, J. Ballestero \& A. Bolaños. 2006. Estimación de la abundancia relativa de tiburones en el Zona Económica Exclusiva de Costa Rica a partir de observaciones a bordo de la flota de palangre de Playas del Coco, Guanacaste, Costa Rica, p. 10-12. In R. Rojas \& I. Zanella (eds.). Memoria: Primer Seminario Taller sobre el estado del conocimiento de la Condrictiofauna de Costa Rica. INBio, Santo Domingo, Heredia, Costa Rica. (Cv, Eg, PiE)

49. Aubry, U. 1995. A new species of the genus Terebra Bruguière, 1789 from Costa Rica. World Shells 14: 30-31. (Bd, MoG)

50. Baker, H.B. 1945. Some American Achatinidae. Nautilus 58: 84-92. (Bd, MoG)

51. Bakus, G.J. 1974. Toxicity in holothurians: A geographical pattern. Biotropica 6: 229-236. (EcH, Eg, Tx)

52. Bakus, G.J. 1975. Marine zonation and ecology of Cocos Island, off Central America. Atoll Res. Bull.179: 1-11. (Ar, Eg)

53. Ball, E.E. \& J. Haig. 1974. Hermit crabs from the tropical eastern Pacific. I. Distribution, color and natural history of some common shallow-water species. Bull. South. California Acad. Sci. 73: 95-104. (CrD, Eg)

54. Ballance, L.T., R.L. Pitman \& P.C. Fiedler. 2006. Oceanographic influences on seabirds and cetaceans of the eastern tropical Pacific: A review. Prog. Oceanog. 69: 360-390. (Av, Eg, Mm)

55. Bamber, R.N. 2009. Sea-spiders. Texto: p. 307-311, Lista de especies, disco compacto: p. 237-238. In I.S. Wehrtmann \& J. Cortés (eds.). Marine Biodiversity of Costa Rica, Central America. Springer, Berlin. (Bd, Pc)

56. Bandy, O.L. \& R.E. Arnal. 1957. Distribution of Recent Foraminifera off the west coast of Central America. Bull. Amer. Assoc. Petrol. Geol. 41: $2037-$ 2053. (Bd, Fo)

57. Banta, W.C. 1991. The bryozoa of the Galápagos. Pp. 371-389. In M.J. James (ed.), Galápagos Marine Invertebrates: Taxonomy, Biogeography, and Evolution in Darwin's Islands. Plenum Press, New York and London. (Bd, $\mathrm{Br}$ )

58. Barckhausen, U., C.R. Ranero, R. Von Huene, S.C. Cande \& H.A. Roesert. 2001. Revised tectonic boundaries in the Cocos Plate off Costa Rica: Implications for the segmentation of the convergent margin and for plate tectonic models. J. Geophys. Res. 106: 19,20719,220. (Ge, TP)

59. Barnard, J.L. 1979. Littoral Gammaridean Amphipoda from the Gulf of California and the Galapagos Islands. Smithsonian Contr. Zool. 271: 1-149. (Bd, CrA)
60. Barnard, J.L. 1991. Amphipoda of the Galápagos Islands. Pp. 193-206. In M.J. James (ed.), Galápagos Marine Invertebrates: Taxonomy, Biogeography, and Evolution in Darwin's Islands. Plenum Press, New York and London. (Bd, CrA)

61. Barrantes, G. \& J. Chaves-Campos. 2009. Birds in coastal and marine environments. Texto: Pp. 469478, Lista de especies, disco compacto: Pp. 479-484. In I.S. Wehrtmann \& J. Cortés (eds.). Marine Biodiversity of Costa Rica, Central America. Springer, Berlin. (Av, Bd)

62. Bartsch, P. \& H.A. Rehder. 1939. Mollusks collected on the Presidential Cruise of 1938. Smithsonian Mis. Coll. 98(10): 1-18. (Bd, Mo)

63. Beck, R.H. 1907. Notes from Clipperton and Cocos islands. Condor 9: 109-110. (Av, Bd)

64. Beebe, W. 1926. The Arcturus Oceanographic Expedition. Zoologica 8: 1-45. (Ep)

65. Beebe, W. \& R. Rose. 1936. La Isla del Coco, Isla de Piratas. Extracto del libro "The Arcturus Adeventure" por William Beebe, Traducción de don León Fernández Guardia. Rev. Col. Sup. Señoritas Año III, Números 3 y 4: 35-43. (Ep, Hi)

66. Beebe, W. \& J. Tee-Van. 1941. Eastern Pacific expeditions of the New Cork Zoological Society. XXV. Fishes from the tropical Eastern Pacific. Part 2. Sharks. Zoologica 26: 93-122. (Bd, PiE)

67. Beebe, W. \& J. Tee-Van. 1941. Eastern Pacific expeditions of the New Cork Zoological Society. XXVI. Fishes from the tropical Eastern Pacific. Part 2. Rays, mantas and chimaeras. Zoologica 26: 245-280. (Bd, $\mathrm{PiE})$

68. Bellon, H., R. Sáenz \& J. Tournon. 1983. K/Ar radiometric ages of lavas from Cocos Island (eastern Pacific). Mar. Geol. 54: M17-M23. (Ge, DR)

69. Bergh, R. 1894. Reports on the dredging operations off the west coasts of Central America to the Galapagos, to the west coast of Mexico, and in the Gulf of California, in charge of Alexander Agassiz, carried on by the U.S. Fish Commission Steamer "Albatross", during 1891, Lieut. Commander Z.L. Tanner, U.S.N., commanding. XIII. Die Opisthobranchien. Bull. Mus. Comp. Zöol. Harvard Coll. XXV: 125-233, plus 12 plates. (Bd, MoG)

70. Bernard, F.R. 1974. Septibranchs of the eastern Pacific (Bivalvia: Anomalodesmata). Allan Hancock Monogr. Mar. Biol. 8: 1-279. (Bd, MoB)

71. Bernard, F.R. 1976. Living Chamidae of the eastern Pacific (Bivalvia: Heterodonta). Nat. Hist. Mus. Los Angeles Contr. Sci. 278: 1-43. (Bd, MoB)

72. Bernard, F.R. 1983.Catalogue of the living Bivalvia of the Easter Pacific Ocean: Bering Strait to Cape Horn. Canadian Special Publication of Fisheries and Aquatic Sciences 61: 1-102. (Bd, Bg, MoB) 
73. Bernard, F.R., S.M. McKinnell \& G.S. Jamieson. 1991. Distribution and zoogeography of the Bivalvia of the eastern Pacific Ocean. Canadian Spec. Publ. Fish. Aquat. Sci. 112. 60 p.

74. Bernecker, A. \& I.S. Wehrtmann. 2009. New records of benthic marine algae and cyanobacteria for Costa Rica, and a comparison with other Central American countries. Hegol. Mar. Res. 63: 219-229. (Al, Bd)

75. Bertsch, H. 1979. Tropical faunal affinities of Opisthobranch from the Panamic Province (Eastern Pacific) Nautilus 93: 57-61. (Bd, MoG)

76. Bertsch, H. 1979. The Eastern Pacific chromodorids (Opisthobranchia. Chromodoridinae). Festivus 11: 44-46. (Bd, MoG)

77. Bessudo, S., G.A. Soler, A.P. Klimley, J.T. Ketchum, A. Hearn \& R. Arauz. 2011. Residency of the scalloped hammerhead shark (Sphyrna lewini) at Malpelo Island and evidence of migration to other islands in the Eastern Tropical Pacific. Env. Biol. Fish. 91: 165-176. (Eg, PiE)

78. Bessudo, S., G.A. Soler, P.A. Klimley, J. Ketchum, R Arauz, A. Hearn, A. Guzmán \& B. Calmettes. 2011. Vertical and horizontal movements of the scalloped hammerhead shark (Sphyrna lewini) around Malpelo and Cocos islands (Tropical Eastern Pacific) using satellite telemetry. Bol. Invest. Mar. Cost. 40 (Supl. Esp.): 91-106. (Eg, PiE)

79. Bigelow, H.B. 1909. Reports of the scientific results of the Expedition to the Eastern Tropical Pacific, in charge of Alexander Agassiz, by the U. S. Fish Commission Steamer "Albatross," from October, 1904, to March, 1905, Lieut. Commander L. M. Garrett, U.S.N., commanding. XVI. The Medusae. Mem. Mus. Comp. Zoöl. Harvard Coll. XXXVII: 1-243. (Bd, CnM)

80. Bigelow, H.B. 1911. Reports of the scientific results of the Expedition to the Eastern Tropical Pacific, in charge of Alexander Agassiz, by the U. S. Fish Commission Steamer "Albatross," from October, 1904, to March, 1905, Lieut. Commander L. M. Garrett, U.S.N., commanding. XXIII. The Siphonophorae. Mem. Mus. Comp. Zoöl. Harvard Coll. XXXVIII: 369-408. (Bd, CnH)

81. Bigelow, H.B. 1928. Scyphomedusae from the Arcturus Oceanographic Expedition. Zoologica 8: 495524. (Bd, CnM)

82. Bigelow, H.B. 1931. Siphonophorae from the Arcturus Oceanographic Expedition. Zoologica 8: 525592. $(\mathrm{Bd}, \mathrm{CnH})$

83. Biolley, P. 1907. Mollusques de l'Isle del Coco. Museo Nacional de Costa Rica, San José, Costa Rica. 30 p. (Traducido: Biolley, P. 1935. Moluscos de la Isla del Coco. Revista del Colegio Superior de Señoritas (San José) 2(6): 2-18.) (Bd, Mo)
84. Biolley, P. 1935. Indice del género y especies de los moluscos de la Isla del Coco. Rev. Col. Sup. Señoritas (San José) 2(4-5): 16. (Bd, Mo)

85. Bishop, J.A. 1997. New distribution data on three eastern Pacific gastropod species. Festivus 29: 39-40. (Bd, MoG)

86. Boone, L. 1926. Unusual deep-sea Crustacea - some forms secured by the Arcturus Oceanographic Expedition. Zool. Soc. Bull. 29: 69-72. (Bd, Cr, ZP)

87. Boone, L. 1926. A new Family of Crustacea. Preliminary technical description. Zool. Soc. Bull. 29: 73. (Bd, Cr)

88. Boone, L. 1927. The littoral crustacean fauna of the Galapagos Islands. Zoologica 8: 127-288. (Bd, Cr)

89. Boone, L. 1930. Scientific results of the cruises of the yachts "Eagle" and "Ara", 1921-1928, William K. Vanderbilt, Commanding. Crustacea: Stomatopoda and Brachyura. Bull. Vanderbilt Mar. Mus. 2: 1-228. $(\mathrm{Bd}, \mathrm{CrD}, \mathrm{CrS})$

90. Boone, L. 1930. Scientific results of the cruises of the yachts "Eagle" and "Ara", 1921-1928, William K. Vanderbilt, Commanding. Crustacea: Anomura, Macrura, Schizopoda, Isopoda, Amphipoda, Mysidacea, Cirripedia, and Copepoda. Bull. Vanderbilt Mar. Mus. 3: 1-221. (Bd, CrA, CrC, CrD, CrM, CrP)

91. Boone, L. 1932. The littoral crustacean fauna of the Galápagos Islands. Part II - Anomura. Zoologica 14: 1-62. (Bd, CrD)

92. Boone, L. 1933. Scientific results of cruises of the yachts "Eagle" and "Ara", 1921-1928, William K. Vanderbilt, commanding. Coelenterata, Echinodermata and Mollusca. Bull. Vanderbilt Mar. Mus. IV: 1-217. (Bd, Cn, Ec, Mo)

93. Boulay, J.N., J. Cortés, J. Nivia-Ruiz \& I.B. Baums. 2012. Genotypic diversity of the reef-building coral Porites lobata (Dana, 1846) (Scleractinia: Poritidae) at Isla del Coco National Park, Costa Rica. Rev. Biol. Trop. 60 (Suppl. 3): 279-292. (CnA, Gn)

94. Bowman, T.E. 1977. Isopod crustaceans (except Anthuridae) collected on the Presidential Cruise of 1938. Proc. Biol. Soc. Washington 89: 653-666. (Bd, CrI)

95. Bradbury, M.G. 1980. A revision of the fish genus Ogcocephalus with descriptions of new species from the western Atlantic Ocean (Ogcocephalidae: Lophiformes). Proc. California Acad. Sci. 42: 229-285. (Bd, PiA)

96. Bratcher, T. \& R.D. Burch. 1971. The Terebridae (Gastropoda) of Clarion, Socorro, Cocos and Galápagos islands. Proc. California Acad. Sci. $4^{\text {th }}$ Ser. 37: 537-566. (Bd, MoG)

97. Bratcher, T. \& W.O. Cernohorsky. 1987. Living terebras of the World. American Malacologist, Melbourne, Florida, 240 p. (Bd, MoG) 
98. Breedy, O. 2009. Octocorals. Texto: Pp. 161-167, Lista de especies, disco compacto: Pp. 108-111. In I.S. Wehrtmann \& J. Cortés (eds.). Marine Biodiversity of Costa Rica, Central America. Springer, Berlin. $(\mathrm{Bd}, \mathrm{CnA})$

99. Breedy, O. \& J. Cortés. 2008. Octocorals (Coelenterata: Anthozoa: Octocorallia) of Isla del Coco, Costa Rica. Rev. Biol. Trop. 56 (Suppl. 2): 71-77. $(\mathrm{Bd}, \mathrm{CnA})$

100. Breedy, O. \& J. Cortés. 2011. Morphology and taxonomy of a new species of Leptogorgia (Cnidaria: Octocorallia: Gorgoniidae) in Cocos Island National Park, Pacific Costa Rica. Proc. Biol. Soc. Washington 124: 62-69. (Bd, CnA)

101. Breedy, O. \& H.M. Guzman. 2003. Octocorals from Costa Rica: The genus Pacifigorgia (Coelenterata: Octocorallia: Gorgoniidae). Zootaxa 281: 1-60. (Bd, $\mathrm{CnA}$ )

102. Breedy, O., C.P. Hickman, Jr. \& G.C. Williams. 2009 Octocorals in the Galapagos Islands. Galapagos Res. 66: 27-31. (Bd, CnA)

103. Breedy, O., L.P. Van Ofwegen \& S. Vargas. 2012. A new family of soft corals (Anthozoa, Octocorallia, Alcyonacea) from the aphotic tropical eastern Pacific waters revealed by integrative taxonomy. Syst. Biod. 10: 351-359. (Bd, CnA, ZP)

104. Brenes, C.L \& E. Coen. 1987. Variaciones en el patrón de circulación y estructura térmica entre Costa Rica y la Isla del Coco: un transecto en el Océano Pacífico Oriental. Rev. Geofís. 27: 87-102. (OF)

105. Briggs, J.C. 1951. A review of the clingfishes (Gobiesocidae) of the Eastern Pacific with descriptions of new species. Proc. California Zool. Club 1: 57-108. $(\mathrm{Bd}, \mathrm{PiA})$

106. Briggs, J.C. 1955. A monograph of the clingfishes (Order Xenopterygii). Stranford Ichthyol. Bull. 6: 1-224. (Bd, PiA)

107. Broenkow, W.W. 1965. The distribution of nutrients in the Costa Rica Dome in the Eastern Tropical Pacific Ocean. Limnol. Oceanogr. 10: 40-52. (DCR, OQ)

108. Brusca, R.C. \& E.W. Iverson. 1985. A guide to the marine isopod crustacea of Pacific Costa Rica. Rev. Biol. Trop. 33 (Suppl. 1): 1-77. (Bd, CrI)

109. Brusca, R.C. \& I.S. Wehrtmann. 2009. Isopods. Texto: p. 257-264, Lista de especies, disco compacto: p. 206-211. In I.S. Wehrtmann \& J. Cortés (eds.). Marine Biodiversity of Costa Rica, Central America. Springer, Berlin. (Bd, CrI)

110. Buck, G.L. 1994. Kellia suborbicularis (Montagu, 1803 ) an unusual and interesting habitat. Festivus 25: 38. $(\mathrm{Eg}, \mathrm{MoB})$

111. Burke, K. \& J.T. Wison. 1976. Hot Spots on the earth's surface, p. 31-42. In R. Decker \& B. Decker (eds.). Volcanoes and the Earth's Interior. W.H. Freeman, New York. (Ge, Vu)

112. Burkenroad, M.D. 1938. The Templeton Crocker Expedition. XII. Sergestidae (Crustacea: Decapoda) from the Lower California region, with descriptions of two new species and some remarks on the Organ of Pesta in Sergestes. Zoologica 22: 315-329. (Bd, CrD)

113. Bussing, W.A. 1983. A new tropical eastern Pacific labrid fish, Halichoeres discolor endemic to Isla del Coco. Rev. Biol. Trop. 31: 19-23. (Bd, PiA)

114. Bussing, W.A. 1985. Los peces de la Familia Labridae de la costa Pacífica de Costa Rica. Rev. Biol. Trop. 33: 81-98. (Bd, PiA)

115. Bussing, W.A. 1990. New species of gobiid fishes of the genera Lythrypnus, Elacatinus and Chriolepis. Rev. Biol. Trop. 38: 99-118. (Bd, PiA)

116. Bussing, W.A. 1991. A new genus and two new species of tripterygiid fishes from Costa Rica. Rev. Biol. Trop. 39: 77-85. (Bd, PiA)

117. Bussing, W.A. 1991. A new species of eastern Pacific moray eel (Pisces: Muraenidae). Rev. Biol Trop. 39: 97-102. (Bd, PiA)

118. Bussing, W.A. 1997. Chriolepis atrimelum (Gobiidae) a new species of gobiid fish from Isla del Coco, Costa Rica. Rev. Biol. Trop. 45: 1547-1552. (Bd, $\mathrm{PiA})$

119. Bussing, W.A. 2010. A new fish, Peristedion nesium (Scorpaeniformes: Peristediidae) from Isla del Coco, Costa Rica. Rev. Biol. Trop. 58: 1149-1156. (Bd, PiA)

120. Bussing, W.A. \& R.J. Lavenberg. 2003. Four new species of eastern tropical Pacific jawfishes (Opistongathus: Opistognathidae). Rev. Biol. Trop. 51: 529-550. (Bd, PiA)

121. Bussing, W.A. \& M.I. López. 2005. Peces de la Isla del Coco y peces arrecifales de la costa Pacífica de América Central meridional / Fishes of Cocos Island and reef fishes of the Pacific coast of lower Central America. Rev. Biol. Trop. 53 (Supl. 2): 1-192. (Bd, PiA, PiE)

122. Bussing, W.A. \& M. López. 2009. Marine fish. Texto: Pp. 453-458, Lista de especies, disco compacto: Pp. 412-473. In I.S. Wehrtmann \& J. Cortés (eds.). Marine Biodiversity of Costa Rica, Central America. Springer, Berlin. (Bd, PiA, PiE)

123. Cairns, S.D. 1991. A revision of the ahermatypic Scleractinia of the Galápagos and Cocos Islands. Smithsonian Cont. Zool. 504: 1-33. (Bd, CnA)

124. Cairns, S.D. 1991. New records of Stylasteridae (Hydrozoa: Hydroida) from the Galápagos and Cocos Islands. Proc. Biol. Soc. Washington 104: 209-228. $(\mathrm{Bd}, \mathrm{CnH})$ 
125. Cajiao, M.J. 2008. Aspectos legales relacionados con el Parque Nacional Isla del Coco, Costa Rica. Rev. Biol. Trop. 56 (Supl. 2): 207-214. (Lg)

126. Camacho-García, Y.E. 2009. Benthic opisthobranchs. Texto: p. 371-386, Lista de especies, disco compacto: p. 330-347. In I.S. Wehrtmann \& J. Cortés (eds.). Marine Biodiversity of Costa Rica, Central America. Springer, Berlin. (Bd, MoG)

127. Camp, D.K. \& H.G. Kuck. 1990. Additional records of stomatopods crustaceans from Isla del Coco and Golfo de Papagayo, east Pacific Ocean. Proc. Biol. Soc. Washington 103: 847-853. (Bd, CrS)

128. Castellanos-Osorio, I., R.M. Hernández-Flores, Á. Morales-Ramírez \& M. Corrales-Ugalde. 2012. Apendicularias (Urochordata) y quetognatos (Chaetognatha) del Parque Nacional Isla del Coco, Costa Rica. Rev. Biol. Trop. 60 (Suppl. 3): 243-255. (Bd, Ap, Qt)

129. Castillo, P., R. Batiza, D. Vanko, R.E. Malavassi, J. Barquero \& E. Fernández. 1988. Anomalously young and old hot-spot traces: I. Geology and petrology of Cocos Island. Bull. Geol. Soc. Amer. 100: 14001414. (DR, Ge, $\mathrm{Vu})$

130. Cate, C.N. 1969. The eastern Pacific cowries. Veliger 12: 103-119. (Bd, CnG)

131. Cernohorsky, W.O. 1976. The Mitridae of the world, Part I: The Subfamily Mitrinae. Indo-Pac. Mollusca 3(17): 273-528. (Bd, MoG)

132. Cernohorsky, W.O. 1991. The Mitridae of the world, Part 2: The Subfamily Mitrinae concluded and subfamilies Imbricariinae and Cylindromitridae. Monogr. Mar. Mollusca 4: 1-164. (Bd, MoG)

133. Chace, F.A., Jr. 1962. The non-brachyuran decapod crustaceans of Clipperton Island. Proc. U.S. Natl. Mus. 113(3466): 605-635. (Bd, CrD)

134. Chaney, H.W. 1992. Interesting gastropods from the 1992 Cocos Island Expedition. Festivus 24: 86-89. (Bd, MoG)

135. Chaney, H.W. 1993. The collection and observation of living Morum veleroae from Cocos Island, Costa Rica. Festivus 25: 23-28. (Bd, Eg, Mo)

136. Chaney, H.W. 1996. Additional records of Polinices simiae (Gastropoda: Naticidae) in the eastern Pacific. Festivus 28: 82. (Bd, Bg, MoG)

137. Cheng, L. 1985. Biology of Halobates (Heteroptera: Gerridae). Ann. Rev. Entomol. 30: 111-135. (Eg, IM)

138. Child, C.A. 1979. Shallow-water Pycnogonida of the Isthmus of Panama and the coast of Middle America. Smithsonian Contr. Zool. 293: 1-86. (Bd, Pc)

139. Child, C.A. 1992. Pycnogonida of the Southeast Pacific Biological Oceanographic Project (SEPBOP). Smithsonian Contr. Zool. 526: 1-43. (Bd, Pc)
140. Christie, D.M., R.A. Duncan, A.R. McBirney, M.A. Richards, W.M. White, K.S. Harpp \& C.G. Fox. 1992. Drowned islands downstream from the Galapagos hotspot imply extended speciation times. Nature 355: 246-248. (Ev, Ge)

141. Chubb, L.J. 1933. Geology of Galápagos, Cocos and Eastern Islands with petrology of Galápagos. Bernice P. Bishop Museum Bull. 110: 1-67. (Trad. español: La Isla del Coco, Costa Rica, pp. 69-83. Reproducciones Científicas, una expedición y legislación de la Isla del Coco. Inst. Geogr. Costa Rica, San José, Costa Rica, 1963). (Ge)

142. Clark, A.H. 1939. Echinoderms (other than Holothurians) collected on the Presidential Cruise of 1938. Smithsonian Mis. Coll. 98 (11): 1-22. (Bd, Ec)

143. Clark, H.L. 1917. Reports on the scientific results of the expedition to the tropical Pacific in charge of Alexander Agassiz, on the U.S. Fish Commission Steamer "Albatross" from August 1899 to March 1900, Commander Jefferson F. Mooser, U.S.N. commanding. XVIII. Reports on the scientific results of the expedition to the tropical Pacific in charge of Alexander Agassiz, on the U.S. Fish Commission Steamer "Albatross" from October 1904 to March 1905, Lieut. Commander L.M. Garret, U.S.N., commanding. XXX. Ophiuroidea. Bull. Mus. Comp. Zoöl. Harvard Coll. 61: 429-466. (Bd, EcO)

144. Clark. H.L. 1938. The Hancock Pacific Expeditions. Science Monthly 47: 511-518. (Ep)

145. Clark, H.L. 1940. Eastern Pacific expeditions of the New York Zoological Society. XXI. Notes on the Echinoderms from the west coast of Central America. Zoologica 25: 331-352. (Bd, Ec)

146. Clark, H.L. 1948. A report on the Echini of the warmer eastern Pacific, based on the collections of the Velero III. Allan Hancock Pac. Exped. 8: 225 352. (Bd, EcE)

147. Coan, E.V. 1988. Recent eastern Pacific species of the bivalve genus Semele. Veliger 31: 1-42. (Bd, MoB)

148. Coan, E.V. 1990. The Recent eastern Pacific species of the bivalve Family Thraciidae. Veliger 33: 20-55. (Bd, MoB)

149. Coan, E.V. 2000. The eastern Pacific recent species of the Corbulidae (Bivalvia). Malacologia 44: 47-105. $(\mathrm{Bd}, \mathrm{MoB})$

150. Coan, E.V., P.V. Scott \& F. Bernard. 2000. Bivalve Seashells of Western North America. Marine Mollusks from Arctic Alaska to Baja California. Santa Barbara Mus. Nat. Hist. Monogr. 2: 764 p. $(\mathrm{Bd}, \mathrm{MoB})$

151. Collette, B.B. \& H. M. Banford. 2001. Status of the eastern Pacific agujon needlefish Tylosurus pacificus (Steindachner, 1876) (Beloniformes: Belonidae). Rev. Biol. Trop. 49 (Supl. 1): 51-57. (Bd, PiA) 
152. Cortés, J. 1996/1997. Biodiversidad marina de Costa Rica: Filo Cnidaria. Rev. Biol. Trop. 44(3)/45(1): 323-334. (Bd, CnA)

153. Cortés, J. 1997. Biology and geology of eastern Pacific coral reefs. Coral Reefs 16 (Suppl.): S39-S46. (Ar, Eg, Ge)

154. Cortés, J. 2007. Coastal morphology and coral reefs, p. 185-200. In J. Bundschuh \& G.E. Alvarado (eds.). Central America: Geology, Resources and Hazards, Vol. 1. Taylor \& Francis, London. (Ar, Ge)

155. Cortés, J. 2008. Historia de la investigación marina de la Isla del Coco, Costa Rica. Rev. Biol. Trop. 56 (Supl. 2): 1-18. (Hi)

156. Cortés, J. 2009. A history of marine biodiversity scientific research in Costa Rica, p. 47-80. In I.S. Wehrtmann and J. Cortés (eds.). Marine Biodiversity of Costa Rica, Central America. Springer, Berlin. (Hi)

157. Cortés, J. 2009. Zoanthids, sea anemones, and corallimorpharians. Texto: p. 157-159, Lista de especies, disco compacto: p. 105-107. In I.S. Wehrtmann \& J. Cortés (eds.). Marine Biodiversity of Costa Rica, Central America. Springer, Berlin. (Bd, CnA)

158. Cortés, J. 2009. Stony corals. Texto: p. 169-173, Lista de especies, disco compacto: p. 112-118. In I.S. Wehrtmann \& J. Cortés (eds.). Marine Biodiversity of Costa Rica, Central America. Springer, Berlin. $(\mathrm{Bd}, \mathrm{CnA})$

159. Cortés, J. 2012. Marine biodiversity of an Eastern Tropical Pacific oceanic island, Isla del Coco, Costa Rica. Rev. Biol. Trop. 60 (Suppl. 3): 131-185. (Bd, $\mathrm{Al}, \mathrm{Cn}, \mathrm{Cr}, \mathrm{Mo}, \mathrm{PiA}, \mathrm{PiE})$

160. Cortés, J. \& S. Blum. 2008. Life to $450 \mathrm{~m}$ depth at Isla del Coco, Costa Rica. Rev. Biol. Trop. 56 (Suppl. 2): 189-206. (Bd, ZP)

161. Cortés, J. \& H.M. Guzmán. 1998. Organismos de los arrecifes coralinos de Costa Rica: Descripción, distribución geográfica e historia natural de los corales zooxantelados (Anthozoa: Scleractinia) del Pacífico. Rev. Biol. Trop. 46: 55-91. (Bd, CnA, Eg)

162. Cortés, J. \& C.E. Jiménez. 2003. Corals and cora reefs of the Pacific of Costa Rica: history, research and status, p. 361-385. In J. Cortés (ed.). Latin American Coral Reefs. Elsevier Science B.V., Amsterdam. (Ar, Eg)

163. Cortés, J. \& M.M. Murillo. 1985. Comunidades coralinas y arrecifes del Pacífico de Costa Rica. Rev. Biol. Trop. 33: 197-202. (Ar, Eg)

164. Cortés, J. \& I.S. Wehrtmann. 2009. Diversity of marine habitats of the Caribbean and Pacific of Costa Rica, p. 1-45. In I.S. Wehrtmann \& J. Cortés (eds.). Marine Biodiversity of Costa Rica, Central America. Springer, Berlin. (Ar, Eg, ZP)

165. Cortés, J., C. Mora-Baumgartner \& V. Nielsen. 2009. Foraminifera. Texto: p. 131-135, Lista de especies, disco compacto: p. 79-82. In I.S. Wehrtmann \& J. Cortés (eds.). Marine Biodiversity of Costa Rica, Central America. Springer, Berlin. (Bd, Fo)

166. Cortés, J., V. Nielsen \& A. Herrera-Cubilla. 2009. Bryozoans. Texto: p. 413-416, Lista de especies, disco compacto: p. 385-388. In I.S. Wehrtmann \& J. Cortés (eds.). Marine Biodiversity of Costa Rica, Central America. Springer, Berlin. (Bd, Br)

167. Cortés, J., N. Van der Hal \& R.W.M. Van Soest. 2009. Sponges. Texto: p. 137-142, Lista de especies, disco compacto: p. 83-93. In I.S. Wehrtmann \& J. Cortés (eds.). Marine Biodiversity of Costa Rica, Central America. Springer, Berlin. (Bd, Po)

168. Cortés, J., A. Sánchez-Jiménez, A. Rodríguez-Arrieta, G. Quirós-Barrantes, P.C. González \& S. Blum. 2012. Elasmobranchs observed in deepwaters (45330m) at Isla del Coco National Park, Costa Rica (Eastern Tropical Pacific). Rev. Biol. Trop. 60 (Suppl. 3): 257-273. (Bd, PiE, ZP)

169. Crocker, T. 1933. The Templeton Crocker Expedition of the California Academy of Sciences, 1932, No. 2: Introductory statement. The Expedition on yacht Zaca to the Galapagos Archipelago and other islands and coast of Central America and Mexico, March 10 to September 1,1932. Proc. California Acad. Sci. $4^{\text {th }}$ Ser. 21: 3-9. (Ep)

170. Cubero-Pardo, P. \& J. Rodríguez-Fonseca. 2000. Zalophus californianus (Pinnipedia: Otariidae) en Costa Rica. Rev. Biol. Trop. 48: 273. (Bd, Bg, Mm)

171. Cushman, J.A. \& I. McCulloch. 1939. A report on some arenaceous Foraminifera. Allan Hancock Pac. Exped. 6: 1-113. (Bd, Fo)

172. Cushman, J.A. \& I. McCulloch. 1942. Some Virgulininae in the Collections of the Allan Hancock Foundation. Allan Hancock Pac. Exped. 6: 179-230. (Bd, Fo)

173. Cushman, J.A. \& I. McCulloch. 1950. Some Lagenidae in the collections of the Allan Hancock Foundation. Allan Hancock Pac. Exped. 6: 295-364. (Bd, Fo)

174. Cutler, N., E. Cutler \& J.A. Vargas, 1992. Peanut worms (Phylum Sipuncula) from Costa Rica. Rev. Biol. Trop. 40: 153-158. (Bd, Si)

175. Dall, W.H. 1895. Scientific results of explorations by the U.S. Fish Commission Steamer Albatross. No. XXXIV. Report on Mollusca and Brachiopoda dredged in deep water, chiefly near the Hawaiian Islands, with illustrations of hitherto unfigured species from northwest America. Proc. U.S. Natl. Mus. 17(1032): 675-733. (Bd, Ba, Mo, ZP)

176. Dall, W.H. 1896. Insular landshell faunas, especially as illustrated by the data obtained by Dr. G. Baur in the Galápagos Island. Proc. Acad. Nat. Sci. Phila. 48: 395-459. (Bd, MoG) 
177. Dall, W.H. 1896. Diagnoses of new species of mollusks from the west coast of America. Min. Conch. Nautilus 18(1034): 7-20. (Bd, Mo)

178. Dall, W.H. 1900. Additions to the insular land-shell faunas of the Pacific Coast, especially of the Galápagos and Cocos islands. Proc. Acad. Nat. Sci. Phila. 52: 88-106. (Bd, MoG)

179. Dall, W.H. 1902. Illustrations and descriptions of new, unfigured, or imperfectly known shells, chiefly American, in the U.S. National Museum. Proc. US natl. Mus. 24: 499-566. (Bd, MoG)

180. Dall, W.H. 1908. Reports on the dredging operations off the west coasts of Central America to the Galapagos, to the west coast of Mexico, and in the Gulf of California, in charge of Alexander Agassiz, carried on by the U.S. Fish Commission Steamer "Albatross", during 1891, Lieut. Commander Z.L. Tanner, U.S.N., commanding. XXXVII, and Reports on the scientific results of the expedition to the eastern tropical Pacific, in charge of Alexander Agassiz, by the U.S. Fish Commission Steamer "Albatross," from October, 1904, to March, 1905, Lieut. Commander L.M. Garrett, U.S.N., commanding. XIV. The Mollusca and Brachiopoda. Bull. Mus. Comp. Zoöl. Harvard Coll. XLIII: 205-487. (Bd, Mo)

181. Dall, W.H. 1910. Report on a collection of shells from Peru, with a summary of the littoral marine Mollusca of the Peruvian Zoological Province. Proc. US Natl. Mus. 37: 147-294. (Bd. MoG)

182. Dall, W.H. 1910. Summary of the shells of the genus Conus from the Pacific Coast of America in the U.S. National Museum. Proc. U.S. Natl Mus. 38 (1741): 217-228. (Bd, MoG)

183. Dall, W.H. 1917. Summary of the mollusks of the Family Alectrionidae of the West Coast of America. Proc. U.S. Natl. Mus. 51(2166): 575-579. (Bd, MoG)

184. Dall, W.H. 1920. Annotated list of the recent Brachiopoda in the collection of the United States National Museum, with descriptions of thirty-three new forms. Proc. U.S. Natl. Mus. 57(2314): 261-377. $(\mathrm{Bd}, \mathrm{Ba})$

185. Dalrymple, G. \& A. Cox. 1968. Paleomagnetism, potassium-argon ages and petrology of some volcanic rocks. Nature 217: 323-326. (DR, Ge, Vu)

186. D'Attilio, A. \& C.M. Hertz. 1979. The eastern Pacific species of Murex sensu stricto. Festivus 11: 60-63. (Bd, MoG)

187. D'Attilio, A. \& B.W. Myers. 1987. Emended description and designation of lectotypes for Favartia (Murexiella) humilis (Broderip, 1833) and F. (M.) norrisii (Reeve, 1845) and discussion of $F$. (M.) laurae (E.H. Vokes, 1970): Muricidae. Festivus 19: 2-8. (Bd, MoG)
188. D'Attilio, A. \& B.W. Myers. 1988. A new species of Favartia from the eastern Pacific (Gastropoda: Muricidae). Nautilus 102: 106-109. (Bd, MoG)

189. D'Attilio, A., B.W. Myers \& D.R. Shasky. 1987. A new species of Phyllonotus (Muricidae: Muricinae) from Isla del Coco, Costa Rica. Nautilus 101: 162165. (Bd, MoG)

190. Dawson, C.E. 1977. Studies of the eastern Pacific sand stargazers (Pisces: Dactyloscopidae). 4. Gillellus, Sindoscopus new genus, and Heteristius with description of new species. Proc. California Acad. Sci. 41: 125-160. (Bd, PiA)

191. Dean, H.K. 2004. Marine biodiversity of Costa Rica: Class Polychaeta (Annelida). Rev. Biol. Trop. 52 (Suppl. 2): 131-181. (Bd, Py)

192. Dean, H.K. 2009. Polychaetes and echiurans. Texto: p. 181-191, Lista de especies, disco compacto: p. 122-159. In I.S. Wehrtmann \& J. Cortés (eds.). Marine Biodiversity of Costa Rica, Central America. Springer, Berlin. (Bd, Bg, Er, Py)

193. Dean, H.K., J.A. Sibaja-Cordero \& J. Cortés. 2010. Occurrence of the phoronid Phoronopsis albomaculata in Cocos Island, Costa Rica. Pac. Sci. 64: 459462. (Bd, Ph)

194. Dean, H.K., J.A. Sibaja-Cordero, J. Cortés, R. Vargas \& G.Y. Kawauchi. 2010. Sipunculids and Echiurans of Isla del Coco (Cocos Island), Costa Rica. Zootaxa 2557: 60-68. (Bd, Er, Si)

195. Dean, H.K., J.A. Sibaja-Cordero \& J. Cortés. 2012. Polychaetes (Annelida: Polychaeta) of Parque Nacional Isla del Coco, Pacific Costa Rica. Pac. Sci. 66: 347-386. (Bd, Py)

196. Dean, R. \& M. Montoya. 2005. Ornithological observations from Cocos Island, Costa Rica. (April 2005). Zeledonia 9: 62-69. (Av, Bd)

197. Deichmann, E. 1938. Eastern Pacific Expeditions of the New York Zoological Society. XVI. Holothurians from the western coast of Lower California and Central America, and from the Galapagos Islands. Zoologica XXIII: 361-387. (Bd, EcH)

198. Deichmann, E. 1941. Coelenterates collected on the Presidential Cruise of 1938. Smithsonian Mis. Coll. 99(10): 1-17. (Bd, Cn)

199. Deichmann, E. 1941. The Holothurioidea collected by the Velero III during the years 1932 to 1938. Part I. Dendrochirota. Allan Hancock Pac. Exped. 8: 61-195. (Bd, MoH)

200. Deichmann, E. 1958. The Holothurioidea collected by the Velero III and IV during the years 1932 to 1954. Part II. Aspidochirota. Allan Hancock Pac. Exped. 11: 253-349. (Bd, MoH)

201. DeMets, C. 2001. A new estimate for present-day Cocos-Caribbean plate motion: Implications for slip 
along the Central American volcanic arc. Geophys. Res. Lett., 28: 4043-4046. (Ge, TM)

202. DeMets, C., R.G. Gordon \& D.F. Argus. 2010. Geologically current plate motions. Geophys. J. Int. 181: 1-80. (Ge, TM)

203. Demond, J. 1957. Micronesian reef-associated gastropods. Pac. Sci. 11: 275-341. (Bd, MoG)

204. Díaz, J., C.L. Brenes \& S. Neshiva. 1985. Manifestaciones de El Niño 1982-1983 en el transecto Nicoya-Isla del Coco. UNICIENCIA 2: 53-57. (ENSO, OF)

205. Díaz, J., C.L. Brenes \& S. Neshiva. 1986. Variations and heat content $0-200 \mathrm{~m}$ in the Eastern Pacific transect from Costa Rica to Cocos Island, 1982-1984. Trop. Ocean Atm. Newslett. 35: 7-10. OF

206. Díaz-Agras, G. 2008. Revision of the genus Pozziella (Porifera: Poecilosclerida) with description of three new species from the eastern Pacific. Zootaxa 1866: 69-94. (Bd, Po)

207. Díaz-Bolaños, R.E., E.J. Alfaro \& A. Ugalde-Quesada. 2012. Diccionario histórico-toponímico de la Isla del Coco, Costa Rica. Rev. Biol. Trop. 60 (Supl. 3): 1-14. (Hi, Mp)

208. Dixon, T.H. 1993. GPS measurements of relative motion of the Cocos and Caribbean Plates and strain accumulation across the Middle American Trench. Geoph. Res. Let. 20: 2167-2170. (Ge, TP)

209. Downey, M.E. 1968. Catalog of Recent Echinoid Type specimens in the U.S. National Museum Smithsonian Institution and the Museum of Comparative Zoology, Harvard University. U.S. Natl. Mus. Bull. 264: 1-99. (Bd, EcE)

210. Downey, M.E. 1969. Catalog of Recent Ophiuroid Type specimens in major collections in the United States. U.S. Natl. Mus. Bull. 293: 1-239. (Bd, EcO)

211. Downey, M.E. 1975. Asteroidea from Malpelo Island with a description of a new species of the genus Tamaria. In J.B. Graham (ed.). The Biological Investigations of Malpelo Island, Colombia. Smithsonian Contrib. Zool. 176: 86-90. Bd, EcA

212. Dudzik, K.L. 1996. First record of Pelecanus occidentalis (Aves: Pelecanidae) and Phaeton lepturus (Aves: Phaethontidae), at Isla del Coco, Costa Rica. Rev. Biol. Trop. 43: 303-304. (Av, Bd)

213. Durham, J.W. 1962. Scientific results of the Galápagos-Expedition 1953-54 of the International Institute for Submarine Research, Vaduz (Liechtenstein), leader Dr. Hans Hass. Corals from the Galápagos and Cocos Islands. Proc. California Acad. Sci. 4th Ser. 32: 41-56. (Bd, CnA)

214. Durham, J.W. 1966. Coelenterates, especially stony corals, from the Galapagos and Cocos Islands. In R.I. Bowman (ed.). The Galapagos. Proc. Symp. Galapagos Int. Sci. Proj. 15: 123-135. (Bd, CnA)
215. Durham, J.W. \& J.L. Barnard. 1952. Stony corals of the Eastern Pacific collected by the Velero III and the Velero IV. Allan Hancock Pac. Exped. 16: 1-110. $(\mathrm{Bd}, \mathrm{CnA})$

216. DuShane, H. 1974. The Panamic-Galapagan Epitoniidae. Veliger (Suppl.) 16: 1-84. (Bd, MoG)

217. DuShane, H. \& B.C. Draper. 1975. The genus Seila in the Easten Pacific. Veliger 17(4):335-245. (Bd, MoG)

218. Easley, K. \& M. Montoya. 2006. Observaciones ornitológicas en la Isla del Coco, Costa Rica (Mayo 2006). Zeledonia 10: 31-41. (Av, Bd)

219. Edgar, G.J., S.A. Banks, S. Bessudo, J. Cortés, H.M. Guzman, S. Henderson, C. Martinez, F. Rivera, G. Soler, D. Ruiz \& F.A. Zapata. 2011. Variation in reef fish and invertebrate communities with level of protection from fishing across the Eastern Tropical Pacific seascape. Global Ecol. Biogeogr. 20: 730743. (Bg, Cv, Pe, PiA, PiE)

220. Eernisse, D.J. 1993. Observations on chitons from Cocos Island. West. Soc. Malac. Ann. Rep. [for 1992] 25: 2. (Bd, MoP)

221. Efford, I.E. 1973. The distribution of the sand crabs, Hippa strigillata (Stimpson) and Hippa pacifica (Dana) in the eastern Pacific Ocean (Decapoda, Anomura). Crustaceana 23: 119-122. (Bg, Eg, CrD)

222. Emerson, W.K. 1968. A new species of the gastropod genus Morum from the eastern Pacific Ocean. J. Conchyl. 107: 53-55. (Bd, MoG)

223. Emerson, W.K. 1983. New records of prosobranch gastropods from Pacific Panama. Nautilus 97: 119123. (Bd, MoG)

224. Emerson, W.K. 1989. On the occurrence of Charonia tritonis (Linnaeus) in the eastern Pacific (Ranellidae: Cymatiinae). Festivus 33: 145-154. (Bd, MoG)

225. Emerson, W.K. 1991. First records for Cymatium mundum (Gould) in the eastern Pacific Ocean, with comments on the zoogeography of the tropical transPacific Tonnacean and non-Tonnacean prosobranch gastropods with Indo-Pacific faunal affinities in the west American waters. Nautilus 105: 62-80. (Bd, $\mathrm{Bg}, \mathrm{MoG})$

226. Emerson, W.K. 1994. A zoogeographic summary of the marine mollusks of Clipperton Island (Tropical Eastern Pacific Ocean). Festivus 26: 62-71. (Bd, $\mathrm{Bg}, \mathrm{Mo}$ )

227. Emerson, W.K. 1995. A zoogeographic summary of the marine mollusks of the Revillagigedo Islands (Tropical Eastern Pacific Ocean). Festivus 27: 3-18. (Bd, Bg, Mo)

228. Emerson, W.K. \& H.W. Chaney. 1995. A zoogeographic review of the Cypraeidae (Mollusca: Gastropoda) occurring in the eastern Pacific. Veliger 38: 8-21. (Bd, Bg, MoG) 
229. Emerson, W.K. \& W.E. Old, Jr. 1964. Additional records from Cocos Island. Nautilus 77: 90-92. (Bd, $\mathrm{MoG})$

230. Emig, C.C. 2009. Brachipods. Texto: p. 417-420, Lista de especies, disco compacto: p. 389-391. In I.S. Wehrtmann \& J. Cortés (eds.). Marine Biodiversity of Costa Rica, Central America. Springer, Berlin. $(\mathrm{Bd}, \mathrm{Ba})$

231. Engel, C. \& T. Chase. 1965. Composition of basalts dredged from seamounts off the west coast of Central America. USGS Prof. Paper 525: C161-C163. (Ge, $\mathrm{MS}, \mathrm{Vu})$

232. Erisman, B.E., T.H. Konotchick \& S. Blum. 2009 Observations of spawning in the Leather Bass, Dermatolepis dermatolepis (Teleostei: Epinephelidae), at Cocos Island, Costa Rica. Environ. Biol. Fish. 85: 15-20. (Eg, PiA)

233. Everson, G. 1984. In search of Thais planospira. Festivus 16: 113-114. (Bd, Bg, MoG)

234. Faxon, W. 1893. Reports on the dredging operations off the west coasts of Central America to the Galapagos, to the west coast of Mexico, and in the Gulf of California, in charge of Alexander Agassiz, carried on by the U.S. Fish Commission Steamer "Albatross", during 1891, Lieut. Commander Z.L. Tanner, U.S.N., commanding. VI. Preliminary descriptions of new species of Crustacea. Bull. Mus. Comp. Zoöl. Harvard Coll. 24: 149-220. (Bd, Cr)

235. Faxon, W. 1895. Reports on an exploration off the west coasts of Mexico, Central and South America, and off the Galapagos Islands, in charge of Alexander Agassiz, by the U.S. Fish Commission Steamer Albatross, during 1891, Lieut. Commander Z.L. Tanner U.S.N., commanding. XV. The stalk-eyed Crustacea. Mem. Mus. Comp. Zoöl. Harvard Coll. 18: 1-292. $(\mathrm{Bd}, \mathrm{CrD})$

236. Fernández, C. 2008. Flora marina del Parque Nacional Isla del Coco, Costa Rica, Pacífico Tropical Oriental. Rev. Biol. Trop. 56 (Supl. 2): 57-69. (Al, Bd)

237. Fernández, C. \& J.J. Alvarado. 2008. Chlorophyta de la Costa Pacífica de Costa Rica. Rev. Biol. Trop. 56 (Supl. 4): 149-162. (Al, Bd)

238. Fernández, W. 1984. Comments on meteorological and climatological observations on Cocos Island. Rev. Geofís. 20: 9-19. (CA)

239. Fernández-Álamo, M.A. \& J. Färber-Lorda. 2006. Zooplankton and the oceanography of the eastern tropical Pacific: A review. Prog. Oceanogr. 69: 318359. (OF, PlZ)

240. Fernández-García, C., R. Riosmena-Rodríguez, B Wysor, O. Tejada, \& J. Cortés, 2011. Checklist of the Pacific marine macroalgae of Central America. Bot. Mar. 54: 53-73. (Al, Bd, Bg)
241. Ferreira, A.J. 1987. The chiton fauna of Cocos Island, Costa Rica (Mollusca: Polyplacophora) with the description of two new species. Bull. South. California Acad. Sci. 86: 41-53. (Bd, MoP)

242. Fiedler, P.C. \& L.D. Talley. 2006. Hydrography of the eastern tropical Pacific: a review. Prog. Oceanogr. 69: 143-180. (OF)

243. Fields, W.G. \& V.A. Gauley. 1972. A report on the cephalopods collected by Stanford Oceanographic Expedition 20 to the eastern tropical Pacific Ocean, September to November, 1968. Veliger 15: 113-118. (Bd, MoC)

244. Fisher, D.M., T.W. Gardner, P.B. Sak, J. Sanchez, K. Murphy \& P. Vannucchi. 2004. Active thrusting in the inner forearc of an erosive convergent margin, Pacific coast, Costa Rica. Tectonics, 23, TC2007, doi:10.1029/2002TC001464. (Ge, TP)

245. Fisher, W.K. 1928. Sea stars from the Arcturus Oceanographic Expedition. Zoologica 8: 487-493. (Bd, EcA)

246. Foster, J.M., S.E. LeCroy, R.W. Heard \& R. Vargas. 2009. Gammaridean amphipods. Texto: p. 265-274, Lista de especies, disco compacto: p. 212-216. In I.S. Wehrtmann \& J. Cortés (eds.). Marine Biodiversity of Costa Rica, Central America. Springer, Berlin. $(\mathrm{Bd}, \mathrm{CrA})$

247. Fowler, H.W. 1932. The fishes obtained by the Pinchot South Seas Expedition of 1929, with description of one new genus and three new species. Proc. U.S. Natl. Mus. 80(6): 1-16. (Bd, PiA)

248. Fowler, H.W. 1938. The fishes of the George Vandervilt South Pacific Expedition. 1937. Monogr. Acad. Nat. Sci. Philadelphia 2: 1-349. (Bd, PiA, PiE)

249. Fraser, C.M. 1938. Hydroids of the 1932, 1933, 1935, and 1938 Allan Hancock Pacific Expeditions. Allan Hancock Pac. Exped. 4: 129-153. (Bd, CnH)

250. Fraser, C.M. 1943. General account of the scientific work of the Velero III in the eastern Pacific, 19311941, Part I: Historical introduction, Velero III, Personnel. Allan Hancock Pac. Exped. 1: 1-48. (Ep)

251. Fraser, C.M. 1943. General account of the scientific work of the Velero III in the eastern Pacific, 19311941, Part II: Geographic and biological associations. Allan Hancock Pac. Exped. 1: 49-258. (Ep)

252. Fraser, C.M. 1943. General account of the scientific work of the Velero III in the eastern Pacific, 19311941, Part III: a ten-year list of the Velero III collecting stations (Charts 1-115). With an appendix of collecting stations of the Allan Hancock Foundation for the year 1942. Allan Hancock Pac. Exped. 1: 259-431. (Ep)

253. Fraser, C.M. 1948. Hydroids of the Allan Hancock Pacific Expeditions since March, 1938. Allan Hancock Pac. Exped. 4: 179-335. (Bd, CnH) 
254. Freymueller, J.T., J.N. Kellogg \& V. Vega. 1993. Plate motions in the North Andean Region. J. Geophys. Res. 98: 21,853-21,863. (Ge, TM)

255. Friedlander, A., B. Zgliczynski, E. Ballesteros, O. Aburto-Oropeza, A. Bolaños \& E. Sala. 2012. The shallow-water fish assemblage of Isla del Coco National Park, Costa Rica: structure and patterns in an isolated, predator-dominated ecosystem. Rev. Biol. Trop. 60 (Suppl. 3): 321-338. (Cv, Eg, PiA, PiE)

256. Garman, S. 1899. Reports on an exploration off the west coasts of Mexico, Central and South America, and off the Galapagos Islands, in charge of Alexander Agassiz, by the U.S. Fish Commission Steamer "Albatross", during 1891, Lieut. Commander Z.L. Tanner U.S.N., commanding. XXVI. The Fishes. Mem. Mus. Comp. Zoöl. Harvard Coll. 24: 1-432. (Bd, PiA, PiE)

257. Garrison, V.H. 1996. New records of fishes at Isla del Coco, Costa Rica. Bull. Mar. Sci. 58: 861-864. (Bd, $\mathrm{PiA})$

258. Garth, J.S. 1946. Distribution studies of Galápagos Brachyura. Allan Hancock Pac. Exped. 5: 603-638. (Bd, CrD)

259. Garth, J.S. 1948. The Brachyura of the "Askoy" Expedition, with remarks on carcinological collecting in the Panama Bight. Bull. Amer. Mus. Nat. Hist 92: 1-66. (Bd, CrD)

260. Garth, J.S. 1958. Brachyura of the Pacific coast of America. Oxyrhyncha. Tables and Plates. Allan Hancock Pac. Exped. 21: 501-854. (Bd, CrD)

261. Garth, J.S. 1991. Taxonomy, distribution, and ecology of Galápagos Brachyra, p. 123-145. In M.J. James (ed.). Galápagos Marine Invertebrates: Taxonomy, Biogeography, and Evolution in Darwin's Islands. Plenum Press, New York, London. (Bd, CrD)

262. Gasca, R. \& Á. Morales-Ramírez. 2012. Anfípodos hiperídeos (Crustacea: Peracarida) del Parque Nacional Isla del Coco, Costa Rica, Pacífico Tropical Oriental. Rev. Biol. Trop. 60 (Supl. 3): 223-233. (Bd, CrA)

263. Gifford, E.W. 1913. Expedition of the California Academy of Sciences to the Galapagos Islands 19051906. VIII. The birds of the Galapagos Island with observations on the birds of Cocos Island and Clipperton Island (Columbiformes to Pelecaniformes). Proc. California Acad. Sci. Ser 4, 2:1-132. (Av, Bd)

264. Gifford, E.W. 1919. Expedition of the California Academy of Sciences to the Galapagos Islands 19051906. XIII. Field notes on the land birds of the Galapagos Islands and of Cocos Island, Costa Rica. Proc. California Acad. Sci., Ser. 4, 21: 189-258. (Av, Bd)

265. Glassell, S.A. 1937. The Templeton Crocker Expedition. XI. Hermit crabs from the Gulf of California and the west coast of Lower California. Zoologica 22: 241-263. (Bd, CrD)
266. Glynn, P.W. \& J.S. Ault. 2000. A biogeographic analysis and review of the far eastern Pacific coral reef region. Coral Reefs 19: 1-23. (Bg, CnA)

267. Glynn, P.W. \& S.B. Colley. 2009. Survival of brooding and broadcasting reef corals following large scale disturbances: is there any hope for broadcasting species during global warming? Proc. 11th Int. Coral Reef Symp., Ft. Lauderdale 1: 368-372. (Ar, CC, Cv, Eg, ENOS)

268. Gómez, L.D. 1977. La mosca del cangrejo terrestre Cardisoma crassum Smith (Crustacea: Gecarcinidae) en la Isla del Coco, Costa Rica. Rev. Biol. Trop. 25: 59-63. (Eg, CrD)

269. Gore, R.H. 1982. Porcellanid crabs from the coasts of Mexico and Central America (Crustacea: Decapoda: Anomura). Smithsonian Contr. Zool. 363: 1-34. (Bd, CrD)

270. Graham, J.B. 1975. Introduction. In J.B. Graham (ed.). The Biological Investigations of Malpelo Island, Colombia. Smithsonian Contrib. Zool. 176: 1-8. (Ep, Hi)

271. Grau, G. 1959. Pectinidae of the eastern Pacific. Allan Hancock Pac. Exped. 23: 1-308. (Bd, MoB)

272. Greenfield, D.W., D. Hensley, J.W. Wiley \& S.T. Ross. 1970. The Isla Jaltemba coral formation and its zoogeographical significance. Copeia 1970: 180181. (Ar, Bg)

273. Grove, J.S. \& R.J. Lavenberg. 1997. The Fishes of the Galápagos Islands. Stanford Univ. Press, Stanford, California. 863 p. (Bd, Bg, PiA, PiE)

274. Groves, L.T. 1992. California cowries (Cypraeacea): past and present, with notes on Recent tropical eastern Pacific species. Festivus 24: 101-107. (Bd, MoG)

275. Groves, L.T. 1993. The superfamilies of Cypraeacea and Lamellariacea of Isla del Coco, eastern Pacific Ocean. West. Soc. Malacol. Ann. Rep. 1992, 25: 3-5. (Bd, MoG)

276. Guzman, H.M. \& J. Cortés. 1992. Cocos Island (Pacific of Costa Rica) coral reefs after the 1982-83 El Niño disturbance. Rev. Biol. Trop. 40: 309-324. (Ar, Eg, ENOS)

277. Guzman, H.M. \& J. Cortés. 1993. Arrecifes coralinos del Pacífico Oriental Tropical: Revisión y perspectivas. Rev. Biol. Trop. 41: 535-557. (Ar, Eg, ENOS)

278. Guzman, H.M. \& J. Cortés. 2007. Reef recovery 20-yr after the 1982-83 El Niño massive mortality. Mar. Biol. 151: 401-411. (Ar, Eg, ENOS)

279. Haig, J. 1960. The Porcellanidae (Crustacea: Anomura) of the eastern Pacific. Allan Hancock Pac. Exped. 24: 1-440. (Bd, CrD)

280. Haig, J. \& A.W. Harvey. 1991. Three new species of the Pagurus lepidus complex (Decapoda, Anomura, Paguridae) from the eastern Pacific. Contrib. Sci., 
Los Angeles County Nat. Hist. Mus 430:1-11. (Bd, CrD)

281. Haig, J. \& A.J. Provenzano, Jr. 1965. A new genus and two new species of diogenid hermit crabs (Decapoda, Anomura). Crustaceana 9: 199-207. (Bd, CrD)

282. Haig, J., T.S. Hopkins \& T.B. Scandand. 1970. The shallow water anomuran crab fauna of southwestern Baja California, Mexico. Trans. San Diego Soc. Nat. Hist. 16: 13-32. (Bd, CrD)

283. Halstead, B.W. \& D.W. Schall. 1956. A report on poisonous fishes captured during the Wooldrow G. Krieger Expedition to Cocos Island. Pac. Sci. 10: 103-109. (Bd, PiA)

284. Hanna, G.D. \& L.G. Hertlein. 1938. Land and brackish water Mollusca of Cocos Island. Allan Hancock Pac. Exped. 2: 123-135. (Bd, Mo)

285. Hanna, G.D. \& A.M. Strong. 1949. West American mollusks of the genus Conus. Proc. California Acad. Sci. 4th Ser., 26: 247-322. (Bd, MoG)

286. Harold, A.S. \& M. Telford. 1990. Systematics, phylogeny and biogeography of the genus Mellita (Echinoidea, Clypeasteroida). J. Nat. Hist. 24: 987-1026. $(\mathrm{Bd}, \mathrm{Bg}, \mathrm{EcE})$

287. Harpp, K.S., V.D. Wanless, R.H. Otto, K. Hoernle \& R. Werner. 2005. The Cocos and Carnegie aseismic ridges: a trace element record of long-term plumespreading center interaction. J. Petrol. 46: 109-133. (CVC, Ge, TP)

288. Hartman, O. 1939. Polychaetous Annelids. Part I. Aphroditidae to Pisionidae. Allan Hancock Pac. Exped. 7: 1-155. (Bd, Py)

289. Hartman, O. 1939. The Polychaetous Annelids collected on the Presidential Cruise of 1938. Smithsonian Miscel. Coll. 98(13): 1-22. (Bd, Py)

290. Hartman, O. 1940. Polychaetous Annelids. Part II. Chrysopetalidae to Goniadidae. Allan Hancock Pac. Exped. 7: 173-287. (Bd, Py)

291. Harvey, A.W. 1998. Rediscovery and range extension of the Galápagos "Endemic" Pachycheles velerae (Decapoda: Anomura: Porcellanidae). J. Crust. Biol. 18: 746-752. (Bd, CrD)

292. Hastings, P.A. \& D.R. Robertson. 1999. Acanthemblemaria atrata and Acanthemblemaria mangognatha, new species of eastern Pacific barnacle blennies (Chaenopsidae) from Isla del Coco, Costa Rica, and Islas Revillagigedo, Mexico, and their relationships with other barnacle blennies. Rev. Francaise Aquariol. Herpetol. 25: 107-118. (Bd, PiA)

293. Hauff, F., K. Hoernle, P. von deer Bogaard, G. Alvarado \& D. Garbe-Schönberg. 2000. Age and geochemistry of basaltic complexes in western Costa Rica: contributions to the geotectonic evolution of Central America. Geochem. Geophys. Geosyst. 1 (5), 109, doi10.1029/1999GC000020. (Ge, DR, TP, Vu).
294. Heard, R.W. 2002. Annotated checklist and bibliography for the Orden Tanaidacea (Crustacea: Malacostraca: Peracarida) reported from the Pacific coast of the Americas (Alaska to Chile) and associated off shore islands, p. 369-383. In M.E. Hendrickx (ed.). Contribuciones al estudio de los crustáceos del Pacífico Este [Contributions to the Study of East Pacific Crustacea], Vol. 1, Inst. Cien. Mar Limnol., UNAM, México DF, México. (Bd, CrT)

295. Heard, R.W., O. Breedy \& R. Vargas. 2009. Tanaidaceans. Texto: p. 245-256, Lista de especies, disco compacto: p. 204-205. In I.S. Wehrtmann \& J. Cortés (eds.). Marine Biodiversity of Costa Rica, Central America. Springer, Berlin. (Bd, CrT)

296. Heller, E. \& R.E. Snodgrass. 1903. Papers from the Hopkins-Stanford Galapagos Expedition 1898-1899. XV. New fishes. Proc. Washington Acad. Sci. 5: 189229. (Bd, PiA)

297. Heemstra, P.C. \& J.E. Randall. 1993. FAO Species Catalogue, Vol. 16. Groupers of the World (Family Serranidae, Subfamily Epinephelinae). FAO, Roma. (Bd, PiA)

298. Hendrickx, M.E. 1984. The species of Sicyonia H. Milne Edwards (Crustacea: Penaeoidea) of the Gulf of California, Mexico, with a key for their identification and a note on their zoogeography. Rev. Biol. Trop. 32: 279-298. (Bd, CrD)

299. Hendrickx, M.E. 1995. Langostas (Langosta espinosa, bogavantes y cigalas, cigarras y zapateras, langostas de lodo, etc.), p. 383-415. In W. Fischer, F. Krupp, W. Schneider, C. Sommer, K.E. Carpenter \& V.H. Niem (eds.). Guía FAO para la identificación de especies para los fines de la pesca. Pacífico centrooriental. Vol. 1. Plantas e invertebrados. FAO, Roma. $(\mathrm{Bd}, \mathrm{Bg}, \mathrm{CrD})$

300. Hendrickx, M.E. 1995. Camarones, p. 417-537. In W. Fischer, F. Krupp, W. Schneider, C. Sommer, K.E. Carpenter and U.H. Niem (eds.). Guía FAO para la identificación de especies para los fines de la pesca. Pacífico centro-oriental. Vol. 1. Plantas e Invertebrados. FAO, Roma. (Bd, Bg, CrD)

301. Hendrickx, M.E. 1995. Anomuros, p. 539-564. In Fischer, W.; F. Krupp, W. Schneider, C. Sommer, K.E. Carpenter and U.H. Niem (eds.). Guía FAO para la identificación de especies para los fines de la pesca. Pacífico centro-oriental. Vol. 1. Plantas e Invertebrados. FAO, Roma. (Bd, Bg, CrD)

302. Hendrickx, M.E. 1995. Cangrejos, p. 565-636. In W. Fischer, F. Krupp, W. Schneider, C. Sommer, K.E. Carpenter and U.H. Niem (eds.). Guía FAO para la identificación de especies para los fines de la pesca. Pacífico centro-oriental. Vol. 1. Plantas e Invertebrados. FAO, Roma. (Bd, Bg, CrD)

303. Hendrickx, M.E. 2005. Cap. 14. Crustacea 6. Decapoda: Dendrobranchiata, Caridea, Palinura, Anomura 
\& Brachyura, p. 159-194. In M.E. Hendrickx, R.C. Brusca \& L.T. Findley (eds.). A Distributional Checklist of the Macrofauna of the Gulf of California, Mexico. Part I. Invertebrates. [Listado y Distribución de la Macrofauna del Golfo de California, México, Parte I. Invertebrados]. Arizona-Sonora Desert Museum. 429 p. (Bd, Bg, CrD)

304. Hendrickx, M.E. \& A.W. Harvey. 1999. Checklist of anomuran crabs (Crustacea: Decapoda) from the eastern tropical Pacific. Belg. J. Zool. 129: 363-389. (Bd, $\mathrm{CrD})$

305. Henry, D.P. \& P.A. McLaughlin. 1967. A revision of the subgenus Solidabalanus Hoek (Cirripedia, Thoracica) including a description of a new species with complemental males. Crustaceana 12: 43-58. $(\mathrm{Bd}, \mathrm{CrD})$

306. Henry, D.P. \& P.A. McLaughlin. 1986. The Recent species of Megabalanus (Cirripedia, Thoracica) with special emphasis on Balanus tintinnabulum (Linnaeus) sensu lato. Zool. Verh. 235: 1-69. (Bd, CrD)

307. Herrera, W. 1985. Consideraciones climáticas sobre la Isla del Coco, p. 40-44. In L.D. Gómez (ed.). Clima de Costa Rica, Vegetación y Clima de Costa Rica, Vol. 2. Editorial Universidad Estatal a Distancia, San José, Costa Rica. (CA)

308. Hertlein, L.G. 1932. Mollusks and barnacles from Malpelo and Cocos islands. Nautilus 46: 43-45. (Bd, $\mathrm{CrD}, \mathrm{Mo})$

309. Hertlein, L.G. 1935. The Templeton Crocker Expedition of the California Academy of Sciences, 1932. No. 25: The Recent Pectinidae. Proc. California Acad. Sci. 4th ser. 21: 301-328. (Bd, MoB)

310. Hertlein, L.G. 1937. A note on some species of marine mollusks occurring in both Polynesia and the Western Americas. Proc. Amer. Phil. Soc. 78: $303-$ 312. (Bd, Mo)

311. Hertlein, L.G. 1963. Contribution to the biogeography of Cocos Island, including a bibliography. Proc. California Acad. Sci. $4^{\text {th }}$ Ser. 32: 219-289. (Traducción al español de la páginas 221-225, más la bibliografía anotada en: Nuevos apuntes y bibliografía de la Isla del Coco. Instituto Geográfico Nacional, Serie Geográfica No. 2 (1964): 29-70). (Bd, Bb, Bg, Br, Cn, Cr, Ec, Hi, Mo, OF, PiA, PiE)

312. Hertlein, L.G. \& U.S. Grant IV. 1944. The Cenozoic Brachiopoda of western North America. Publ. UCLA Math. Phys. Sci. 3: 1-236. (Bd, Ba)

313. Hertz, J. 1995. Range extension for Thais melons (Duclos, 1932). Festivus 27: 88. (Bg, MoG)

314. Hertz, J. \& K.L. Kaiser. 1998. Colubraria (Colubraria) ochsneri and Colubraria (C.) lucasensis from Isla del Coco, Costa Rica. Festivus 30: 35-39. (Bd, $\mathrm{MoG})$
315. Hertz, J. \& K.L. Kaiser. 1998. Gastrochaena (Rocellaria) ovata Sowerby, 1834, and Scalenostoma subulata (Broderip, 1832), sharing the same niche. Festivus 30: 85-88. (Eg, MoB)

316. Hey, R. 1977. Tectonic evolution of the Cocos-Nazca spreading center. Geol. Soc. Amer. Bull. 88: 14041420. (Ge, TP)

317. Hey, R., G.L. Johnson \& A. Lowrie. 1977. Recent plate motions in the Galápagos area. Geol. Soc. Amer. Bull. 88: 1385-1403. (Ge, TP)

318. Hidalgo, H. \& E.J. Alfaro. 2012. Global Model selection for evaluation of climate change projections in the Eastern Tropical Pacific Seascape. Rev. Biol. Trop. 60 (Suppl. 3): 67-81. (CA, CC)

319. Hochberg, F.G. \& Y.E. Camacho-García. 2009. Squids and octopus. Texto: p. 399-407, Lista de especies, disco compacto: p. 379-382. In I.S. Wehrtmann \& J. Cortés (eds.). Marine Biodiversity of Costa Rica, Central America. Springer, Berlin. (Bd, MoC)

320. Hollmann, M. 1996. Polinices (Mammilla) simiae on Isla del Coco, Costa Rica: another Indo-Pacific invader into the Panamic Province. Festivus 28: 24-29. (Bd, Bg, MoG)

321. Holthuis, L.B. 1952. A general revision of the Palaemonidae (Crustacea: Decapoda: Natantia) of the Americas. II. The subfamily Palaemoninae. Occ. Papers Allan Hancock Fund. 12: 1-396. (Bd, CrD)

322. Howard, A.D. 1952. Pteropods collected by the Allan Hancock Foundation. Min. Conchol. Club South. California 121: 12-14. (Bd, MoG)

323. Hoyle, W.E. 1904. Reports on the dredging operations off the west coast of Central America to the Galapagos, to the west coast of Mexico, and in the Gulf of California, in charge of Alexander Agassiz, carried on by the U. S. Fish Commission Steamer "Albatros," during 1891, Lieut. Commander Z.L. Tanner, U.S.N., commanding, XXIX. Reports on the Scientific results of the expedition to the tropical Pacific, in charge of Alexander Agassiz, on the U. S. Fish Commission Steamer "Albatross," from August, 1899, to March, 1900, Commander Jefferson T. Moser, U.S.N., commanding, V. Cephalopoda. Bull. Mus. Comp. Zoöl. Harvard Coll. XLIII (1): 1-71. $(\mathrm{Bd}, \mathrm{MoC})$

324. Hunter, J.R. \& C.T. Mitchell. 1966. Association of fishes with flotsam in the offshore waters of Central America. Fish. Bull. 66: 13-29. (Eg, PiA)

325. Hutsell, K.C. 1993. Conus mahogani (Reeve, 1943) the first specimen from Cocos Island, Costa Rica. Festivus 25: 20. (Bd, Bg, MoG)

326. Hutsell, K.C. 1993. Haliotis roberti at Cocos Island, Costa Rica. Festivus 25: 28. (Bd, Bg, MoG) 
327. Hutsell, K.C. 1994. Persicula pulchella (Kiener, 1834) “A numbing experience". Festivus 26: 56-57. (Eg, MoG)

328. Ingram, W.M. 1945. An extension of the range of Cypraea rashleighana Melvill. Nautilus 58: 106-107. (Bd, Bg, MoG)

329. Ingram, W.M. 1947. Fossil and recent Cypraeidae of the western regions of the Americas. Bull. Amer. Paleont. 31: 43-124. (Bd, MoG)

330. Iwamoto, T. 1979. Eastern Pacific macrourine grenadiers with seven branchiostegal rays (Pisces: Macrouridae). Proc. California Acad. Sci. 42: 135-179. (Bd, PiA)

331. Iwamoto T. \& J.E. McCosker. 2001. Notes on Galápagos grenadiers (Pisces, Gadiformes, Macrouridae), with the description of a new species of Coryphaenoides. Rev. Biol. Trop. 49 (Suppl. 1): 21-27. (Bd, PiA)

332. Iwamoto, T. \& Y.I. Sazonov. 1988. A review of the southeastern Pacific Coryphaenoides (sensu lato) (Pisces, Gadiformes, Macrouridae). Proc. California Acad. Sci. 45: 35-82. (Bd, PiA)

333. Iwamoto, T. \& W. Schneider. 1995. Macrouridae, Granaderos, p. 1246-1265. In W. Fischer, F. Krupp, W. Schneider, C. Sommer, K.E. Carpenter \& V.H. Niem (eds.). Guía FAO para la identificación de especies para los fines de la pesca. Pacífico centrooriental. Vol. 3, Vertebrados-Parte 2. FAO, Rome. (Bd, $\mathrm{PiA})$

334. Jiménez-Cueto, S., E. Suárez-Morales \& Á. MoralesRamírez. 2012. Poliquetos holoplanctónicos (Annelida: Polychaeta) del Parque Nacional de Isla del Coco, Costa Rica. Rev. Biol. Trop. 60 (Supl. 3): 207-222. (Bd, PlZ, Py)

335. Kabat, A.R. 2000. Results of the Rumphius Biohistorical Expedition to Ambon (1990). Part 10. Mollusca, Gastropoda, Naticidae. Zool. Med. Leiden 73: 345-380. (Bd, MoG)

336. Kaiser, K.L. 1998. Cypraea talpa on eggs and a live Cymatium (Gutturnium) muricinum, both at Isla del Coco, Costa Rica. Festivus 30: 28-29. (Eg, MoG)

337. Kaiser, K. L. 1999. Oliva foxi (Gastropoda: Olividae) at Isla Montuosa, Golfo de Chiriquí, Panamá. The Festivus 31: 51, fig. 6: 49. (Bd, Bg, MoG)

338. Kaiser, K.L. 1999. Growth series of common molluscan species (Family Muricidae). Festivus 31: 98-100. (Eg, MoG)

339. Kaiser, K.L. 2001. Comments on four Muricoidean (Mollusca) species formerly endemic to Isla del Coco found at Isla de Malpelo. Festivus 33: 3-7. (Bd, Bg, $\mathrm{MoG})$

340. Kaiser, K.L. 2001. Growth changes in Caducifer cinis Reeve, 1846 (Mollusca: Buccinidae) from the Panamic Province. Festivus 33: 27-28. (Eg, MoG)
341. Kaiser, K.L. 2002. Coralliophila neritoidea (Lamarck, 1816) (Gastropoda: Muricidae) reported from Panamá and Costa Rica. Festivus 34: 99-100. (Bd, Bg, MoG)

342. Kaiser, K. L. \& C.W. Bryce. 2001. The recent molluscan marine fauna of Isla Malpelo, Colombia. Festivus 33 (Occasional Paper 1): 1-149. (Bd, Bg, Mo)

343. Kaiser, K.L. \& C.M. Hertz. 2001. Notes on Rhizochilus antipathum Steenstrup, 1850 (Gastropoda: Coralliophilidae) with new records from Île Clipperton and Isla del Coco (tropical eastern Pacific). Festivus 33: 87-94. (Bd, Bg, MoG)

344. Kelmo, F. \& R. Vargas. 2002. Anthoathecatae and Leptothecatae hydroids from Costa Rica (Cnidaria: Hydrozoa). Rev. Biol. Trop. 50: 599-627. (Bd, CnH)

345. Kessler, W.S. 2006. The circulation of the eastern tropical Pacific: a review. Prog. Oceonogr. 69: 181217. (OF)

346. Kim, W. \& L.G. Abele. 1988. The snapping shrimp genus Alpheus from the eastern Pacific (Decapoda: Caridea: Alpheidae). Smithsonian Contr. Zool. 454: 1-119. (Bd, CrD)

347. Kimura, G., E.A. Silver, P. Blum et al. 1997. Costa Rica Accretionary Wedge Sites 1039-1043. Proc. Ocean Drilling Program, Init. Repts., 170: 1-247. (Ge, TM)

348. Kohin, S., R. Arauz, D. Holts \& R. Vetter. 2006. Preliminary results: behavior and habitat preferences of silky sharks (Carcharhinus falciformis) and a big eye thresher shark (Alopias superciliosus) tagged in the Eastern Tropical Pacific, p. 17-19. In R. Rojas \& I. Zanella (eds.). Memoria: Primer Seminario Taller sobre el estado del conocimiento de la Condrictiofauna de Costa Rica. INBio, Santo Domingo, Heredia, Costa Rica. (Cm, Eg, PiE)

349. Kramp, P.L. 1956. Medusae collected in the eastern tropical Pacific by Cyril Crossland in 1924-1925. Vidensk. Medd. Dansk naturh. Foren. 118: 1-6. (Bd, $\mathrm{CnM}$ )

350. Kronenberg, G.C. 1994. Columbella sonsonatensis (Mörch, 1860) from Cocos Island, Costa Rica (Gastropoda: Columbellidae). Festivus 26: 101. (Bd, MoG)

351. Kume, S. \& J. Joseph. 1969. Size composition and sexual maturity of billfish caught by the Japanese longline fishery in the Pacific Ocean east of $130^{\circ} \mathrm{W}$. Bull. Far Seas Fish. Res. Lab. 2: 115-162. (Pe, PiA)

352. LaFemina, P., T. H. Dixon, R. Govers, E. Norabuena, H. Turner, A. Saballos, G. Mattioli, M. Protti \& W. Strauch. 2009. Fore-arc motion and Cocos Ridge collision in Central America. Geochem. Geophys. Geosyst. 10, Q05S14, doi:10.1029/2008GC002181. (Ge, CVC, TP) 
353. Laguarda-Figueras, A. \& F.A. Solís-Marín. 2009. Holothuria (Cystipus) casoae a new species of sea cucumber (Echinodermata: Holothuroidea) from the central-eastern Pacific Ocean. Scient. Mar. 73: 573578. (Bd, EcH)

354. Lalicker, C.G. \& I. McCulloch. 1940. Some Textulariidae of the Pacific Ocean. Allan Hancock Pac. Exped. 6: 115-143. (Bd, Fo)

355. Landry, C., L.B. Geyer, Y. Arakaki, T. Uehara \& S.R. Palumbi. 2003. Recent speciation in the Indo-West Pacific: rapid evolution of gamete recognition and sperm morphology in cryptic species of sea urchin. Proc. R. Soc. Lond. B 270: 1839-1847. (EcE, Ev)

356. Lattig, P. \& S.D. Cairns. 2000. A new species of Tethocyathus (Cnidaria: Anthozoa: Scleractinia: Caryophylliidae), a trans-isthmian azooxanthellate species. Proc. Biol. Soc. Washington 113: 590-595. (Bd, CnA)

357. Lemaitre, R. \& P.A. McLaughlin. 1996. Revision of Pylopagurus and Tomopagurus (Crustacea: Anomura: Paguridae), with the descrption of new genera and species. Part V. Anisopagurus McLaughlin, Manucomplanus McLaughlin and Protoniopagurus new genus. Bull. Mar. Sci. 59: 89-141. (Bd, CrD)

358. Lemaitre, R. \& G.E. Ramos. 1992. A collection of Thalassinidea (Crustacea: Decapoda) from the Pacific coast of Colombia, with description of a new species and a checklist of eastern Pacific species. Proc. Biol. Soc. Washington 105: 343-358. (Bd, CrD)

359. Lemoine, M.P. 1929. Les Corallinacées l'Archipel des Galapagos et du Golfe de Panama. Arch. Mus. Hist. Nat., Paris 4: 47-88.

360. Lessios, H.A. 2010. Speciation in sea urchins, Pp. 91-101. In L.G. Harris, S.A. Bottger, C.W. Walter \& M.P. Lesser (eds.). Echinoderms: Durham. CRC Press, London. (EcE, Ev)

361. Lessios, H.A., B.D. Kessing, G.M. Wellington \& A. Graybeal. 1996. Indo-Pacific echinoids in the tropical eastern Pacific. Coral Reefs 15: 133-142. (Bg, EcE)

362. Lessios, H.A., B.D. Kessing \& D.R. Robertson. 1998. Massive gene flow across the world's most potent marine biogeographic barrier. Proc. R. Soc. London, Ser. B 265: 583-588. (Bg, EcE, Gn)

363. Lessios, H.A., B.D. Kessing, D.R. Robertson \& G. Pauly. 1999. Phylogeographic of the pantropical sea urchin Eucidaris in relation to land barriers and ocean currents. Evolution 53: 806-817. (Bg, EcE, Gn)

364. Lessios, H.A., J. Kane \& D.R. Robertson. 2003. Phylogeography of the Pantropical sea urchin Tripneustes: contrasting patterns of population structure between oceans. Evolution 57: 2026-2036. (Bg, EcE, $\mathrm{Eg}, \mathrm{Gn}$ )

365. Lindberg, D.R. \& J.H. McLean. 1981. Tropical Eastern Pacific limpets of the Family Acmaeidae
(Mollusca, Archaeogastropoda): Generic criteria and description of six new species from the mainland and the Galápagos Islands. Proc. California Acad. Sci. 42: 323-339. (Bd, MoG)

366. Linsley, B.K. Dunbar; R.E., G.M. Wellington, \& D.A. Mucciarone. 1994. A coral-based reconstruction of Intertropical Convergence Zone over Central America since 1707. J. Geophys. Res. 88: 9977-9994.

367. Lizano, O.G. 2001. Batimetría de la plataforma insular alrededor de la Isla del Coco, Costa Rica. Rev. Biol. Trop. 49 (Supl. 2): 163-170. (Go)

368. Lizano, O. 2006. Algunas características de las mareas en la costa Pacífica y Caribe de Centroamérica. Cienc. Tecn. 24: 51-64. (OF)

369. Lizano, O.G. 2008. Algunas características dinámicas de las aguas alrededor de la Isla del Coco, Costa Rica. Rev. Biol. Trop. 56 (Supl. 2): 31-48. (OF)

370. Lizano, O.G. 2012. Rasgos morfológicos alrededor de la Isla del Coco y de sus montes submarinos vecinos, Pacífico de Costa Rica. Rev. Biol. Trop. 60 (Supl. 3): 43-51. (Go, ZP)

371. Lizano, O.G., L.G. Loría, E.J. Alfaro \& M. Badilla. 2008. Distribución espacial de radionucleídos en sedimentos marinos de Bahía Culebra y el Golfo de Nicoya, Pacífico, Costa Rica. Rev. Biol. Trop. 56 (Supl. 4): 83-90. (CtR, Sd)

372. Long, D.J., J.E. McCosker, S. Blum \& A. Klapfer. 2011. Tropical Eastern Pacific records of the Prickly shark, Echinorhinus cookei (Chondrichthyes: Echinorhinidae). Pac. Sci. 65: 433-440. (Bg, PiE)

373. Lonsdale, P.F. \& K.D. Klitgord. 1978 Structure and tectonic history of the eastern Panama basin, Geol. Soc. Amer. Bull. 89: 981-999. (Ge, TM)

374. López-Garro, A., I. Zanella, G. Golfín-Duarte \& M. Pérez-Montero. 2012. First record of the blacktip reef shark Carcharhinus melanopterus (Carcharhiniformes: Carcharhinidae) from the Eastern Tropical Pacific. Rev. Biol. Trop. 60 (Suppl. 3): 275-278. (Bd, $\mathrm{Bg}, \mathrm{PiE})$

375. Ludwig, H. 1887. Die von G. Chierchia auf der Fart der Kgl. Ital. Corvette "Vettor Pisani" gesammelten Holothurien. Zool. Jahrb. 2: 1-36. (Bd, EcH)

376. Ludwig, H. 1894. Reports on an exploration off the west coast of Mexico, Central and South America, and off the Galapagos Islands, in charge of Alexander Agassiz, by the U.S. Fish Commission Steamer "Albatross", during 1891, Lieut. Commander Z.L. Tanner, U.S.N., commanding. XII. The Holothurioidea. Mem. Mus. Comp. Zoöl. Harvard Coll. XVII(3): 1-183. (Bd, EcH)

377. Ludwig, H.L. 1905. Reports on an exploration off the west coast of Mexico, Central and South America, and off the Galapagos Islands, in charge of Alexander Agassiz, by the U. S. Fish Commision Steamer 
"Albatros", during 1891. XXXV. Reports on the Scientific results of the expedition to the Tropical Pacific in charge of A. Agassiz on the Fish Commision Steamer "Albatros", from August, 1899 to March, 1900. VII. Asteroidea. Mem. Mus. Comp. Zoöl. Harvard Coll. XXXII (7): 1-292. (Bd, EcA)

378. Luke, S.R. 1977. Catalog of the benthic invertebrate collections. I. Decapod Crustacea and Stomatopoda. Scripps Institution of Oceanography Reference Series No. 77-9: 72 p. (Bd, CrD)

379. Luke, S.R. 1995. Catalog of the Benthic Invertebrate Collections of the Scripps Institution of Oceanography. Mollusca. Scripps Institution of Oceanography Reference Series No. 95-24: 477 p. (Bd, Mo)

380. Luke, S.R. 1998. Catalog of the Benthic Invertebrate Collections of the Scripps Institution of Oceanography. Coelenterata. Scripps Institution of Oceanography Reference Series No. 98-02: 58 p. (Bd, Cn)

381. Lütken, C.F. \& Th. Mortensen. 1899. Reports on an exploration off the west coast of Mexico, Central and South America, and off the Galápagos Islands, in charge of Alexander Agassiz, by the U. S. Fish Commission Steamer "Albatross," during 1891, Lieut. Commander Z. L. Tanner, U.S.N., commanding. XXV. The Ophiuridæ. Mem. Mus. Comp. Zoöl. Harvard Coll. XXIII (2): 93-208. (Bd, EcO)

382. Macintyre, I.G., P.W. Glynn \& J. Cortés 1993. Holocene reef history in the eastern Pacific: Mainland Costa Rica, Caño Island, Cocos Island, and Galápagos Islands. Proc. 7th Int. Coral Reef Symp., Guam 2: 1174-1184. (Ar, Ge)

383. Magaña, V.O., J.A. Amador \& S. Medina. 1999. The mid-summer drought over Mexico and Central America. J. Climate 12: 1577-1588. (CA)

384. Magaña-Cubillo, J.A. \& J. Espinosa. 2009. Bivalves. Texto: p. 387-398, Lista de especies, disco compacto: p. 348-378. In I.S. Wehrtmann \& J. Cortés (eds.). Marine Biodiversity of Costa Rica, Central America. Springer, Berlin. (Bd, MoB)

385. Malavassi, E. 1981-1982. Visita al Parque Nacional Isla del Coco. Rev. Geográf. Amér. Central 15-16: 211-216. (Ep)

386. Maldonado, T.J. \& E.J. Alfaro. 2012. Revisión y comparación de escenarios de Cambio Climático para el Parque Nacional Isla del Coco, Costa Rica. Rev. Biol. Trop. 60 (Supl. 3): 83-112. (CA, CC)

387. Maluf, L.Y. 1988. Composition and distribution of the central eastern Pacific echinoderms. Nat. Hist. Mus. L.A. County, Tech. Rep. 2: 1-242. (Bd, Bg, Ec)

388. Maluf, L.Y. 1991. Echinoderm fauna of the Galápagos Islands, p. 345-367. In M.J. James (ed.). Galápagos Marine Invertebrates: Taxonomy, Biogeography, and Evolution in Darwin's Islands. Plenum Press, New York and London. (Bd, Bg, Ec, Ev)
389. Manning, R.B. 1972. Three new stomatopod crustaceans of the Family Lysiosquillidae from the eastern Pacific Region. Proc. Biol. Soc. Washington 85: 271278. (Bd, CrD)

390. Marenzeller, E. 1904. Reports on the dredging operations off the west coasts of Central America to the Galapagos, to the west coast of Mexico, and in the Gulf of California, in charge of Alexander Agassiz, carried on by the U.S. Fish Commission Steamer "Albatross", during 1891, Lieut. Commander Z.L. Tanner, U.S.N., commanding. XXXIII. Stein- und Hydro-Korallen. Bull. Mus. Comp. Zoöl. Harvard Coll XLIII: 75-87. (Bd, CnA, CnH)

391. Martens, C.E. von. 1902. Die Meeres-Conchylien der Cocos-Insel. Sitz.-Ber. Gesel. Nat. Freu. Sitzung vom 17 Juni, 1902, no. 6: 137-141. (Bd, MoG)

392. May-Collado, L. 2009. Marine mammals. Texto: p. 479-495, Lista de especies, disco compacto: p. 485490. In I.S. Wehrtmann and J. Cortés (eds.). Marine Biodiversity of Costa Rica, Central America. Springer, Berlin. (Bd, Mm)

393. May-Collado, L., T. Gerrodette, J. Calambokidis, K. Rasmussen \& I. Sereg. 2005. Patterns of cetacean sighting distribution in the Pacific Exclusive Economic Zone of Costa Rica based on data collected from 1979-2001. Rev. Biol. Trop. 53: 249-263. (Bg, $\mathrm{Eg}, \mathrm{Mm})$

394. McCartney, M.A., G. Keller \& H.A. Lessios. 2000. Dispersal barriers in tropical oceans and speciation of Atlantic and eastern Pacific Echinometra sea urchins. Mol. Ecol. 9: 1391-1400. (Bg, EcE, Ev, Gn)

395. McCosker, J.E. 1988. A revision of the snake-eel genus Callechelys (Anguilliformes: Ophichthidae) with the description of two new Indo-Pacific species and a new callechelyin genus. Proc. California Acad. Sci. 50: 185-215. (Bd, PiA)

396. McCosker, J.E. \& R.H. Rosenblatt. 1975. Fishes collected at Malpelo Island. In J.B. Graham (ed.). The Biological Investigations of Malpelo Island, Colombia. Smithsonian Contrib. Zool. 176: 91-93. $\mathrm{Bd}, \mathrm{Bg}, \mathrm{PiA}, \mathrm{PiE}$

397. McCosker, J.E. \& R.H. Rosenblatt. 1995. Muraenidae (Morenas), p. 1303-1314. In W. Fischer, F. Krupp, W. Schneider, C. Sommer, K.E. Carpenter \& V.H. Niem (eds.). Guía FAO para la identificación de especies para los fines de la pesca. Pacífico centro-oriental. Vol. 3, Vertebrados-Parte 2. FAO, Rome. (Bd, Bg, PiA)

398. McCosker, J.E. \& R.H. Rosenblatt. 1998. A revision of the eastern Pacific snake-eel genus Ophichthus (Anguilliformes: Ophichthidae) with the description of six new species. Proc. California Acad. Sci. 50: 397-432. (Bd, PiA)

399. McCosker, J.E. \& R.H. Rosenblatt. 2010. The fishes of the Galápagos Archipelago: an update. Proc. 
California Acad. Sci. $4^{\text {th }}$ Ser 61 (Suppl. II): 167-195. (Bd, Bg, PiA)

400. McCosker, J.E., J.S. Stephens \& R.H. Rosenblatt. 2003. Cottoclinus canops, a new genus and species of blenny (Perciformes: Labrisomidae) from the Galápagos Islands. Proc. California Acad. Sci. 54: 155-160. (Bd, PiA)

401. McLaughlin, P.A. 1981. Revision of Pylopagurus and Tomopagurus (Crustacea: Decapoda: Paguridae), with the descriptions of new genera and species: Part II. Rhodochirus McLaughlin and Phimochirus McLaughlin. Bull. Mar. Sci. 31: 329-365. (Bd, CrD)

402. McLaughlin, P.A. 1982. Revision of Pylopagurus and Tomopagurus (Crustacea: Decapoda: Paguridae), with the descriptions of new genera and species: Part III. Agaricochirus McLaughlin, and Enallopaguropsis McLaughlin. Bull. Mar. Sci. 32: 823-855. (Bd, CrD)

403. McLean, J.H. 1969. New species of tropical eastern Pacific Gastropoda. Malac. Rev. 2: 115-130. (Bd, $\mathrm{MoG})$

404. Meisler, M.R. \& R.J. Lavenberg. 1998. A new species (Serranidae: Serranus) from Isla del Coco, p. 115. In G.R. Allen \& D.R. Robertson. 1998. Peces del Pacífico Oriental Tropical. Crawford House Press, Bathhurst, Australia. (Bd, PiA)

405. Mejía-Falla, P.A. \& A.F. Navia. 2011. Relationship between body size and geographic range size of elasmobranchs from the Tropical Eastern Pacific: An initial approximation for their conservation. Cienc. Mar. 37: 305-321. (Bg, Cv, Eg, PiE)

406. Merrill, G.P. 1893. Reports on the dredging operations off the west coasts of Central America to the Galápagos, to the west coast of Mexico, and in the Gulf of California, in charge of Alexander Agassiz, carried on by the U.S. Fish Commission Steamer "Albatross", during 1891, Lieut. Commander Z.L. Tanner, U.S.N., commanding. V. Report upon rocks collected from the Galápagos Islands. Bull. Mus. Comp. Zoöl. Harvard Coll. 16: 235-237. (Ge)

407. Meschede, M. \& U. Barckhausen. 2001. The relationship of the Cocos and Carnegie ridges: age constraints from paleogeographic reconstructions. Int J. Earth Sci. 90: 386-392. (CVC, DR, Ge)

408. Meschede, M., U. Barckhausen \& H.U. Worm. 1998. Extinct spreading on the Cocos Ridge. Terra Nova 10: 211-216. (CVC, Ge)

409. Meschede, M., U. Barckhausen \& H.U. Worm. 2000. Desarrollo del centro de dispersión entre las placas de Coco y Nazca y los trazos de los puntos calientes. Rev. Geol. Amér. Central 23: 5-16. (Ge, TM)

410. Mestas-Nuñez, A.M. \& A.J. Millar. 2006. Interdecadal variability and climate change in the eastern tropical Pacific: A review. Prog. Oceanogr. 69: $267-$ 284. (CA, CC, VC)

411. Møller, P.R., W. Schwarzhans \& J.G. Nielsen. 2005. Review of the American Dinematichyini (Teleostei: Bythitidae). Part II. Ogilbia. Aqua 10: 133-207. (Bd, PiA)

412. Montoya, M. 1983. Los moluscos marinos de la Isla del Coco. I. Lista anotada de especies. Brenesia 21: 325-353. (Bd, Mo)

413. Montoya, M. 1983. A 3000 miles range extension: Charonia tritonis tritonis in the eastern Pacific. Hawaiian Shell News 31(11): 8. (Bg, MoG)

414. Montoya, M. 1984. Marine mollusks of Cocos Island, Costa Rica. I. Bibliographic compilation of species. West. Soc. Malacol., Ann. Rep. 1983, 16: 33-44. (Bb, Mo)

415. Montoya, M. 1988. Molluscan fauna of Cocos Island, Costa Rica, based on visits from 1983-1987: Preliminary report. West. Soc. Malacol., Ann. Rep. 1987, 20: 30. (Bd, Mo)

416. Montoya, M. 2003. Sobre la formación de una colonia de Sula dactylatra (Pelecaniformes: Sulidae) en la Isla del Coco, Costa Rica. Zeledonia 7: 24-28. (Av, Bg, Eg)

417. Montoya, M. 2003. Aves de la isla del Coco. Lista de Especies/Birds of Cocos Island. Species list/Oiseaux de l'Île de Cocos. Liste des éspèces. Zeledonia 7:2937. (Av)

418. Montoya, M. 2006. Aves acuáticas de la Isla del Coco, Costa Rica. Humedal de la Convensión de Ramsar. Zeledonia 10: 42-52. (Av)

419. Montoya, M. 2007. Notas históricas sobre la ornitología de la Isla del Coco, Costa Rica. Brenesia 68: 37-57. (Av, Hi)

420. Montoya, M. 2008. Aves marinas de la Isla del Coco, Costa Rica y su conservación. Rev. Biol. Trop. 56 (Supl. 2): 133-149. (Av, Cv)

421. Montoya, M. 2008. La presencia de otáridos (Carnivora: Otariidae) en la Isla del Coco, Costa Rica. Rev. Biol. Trop. 56 (Supl. 2): 151-158. (Hi, Mm)

422. Montoya, M. \& K.L. Kaiser. 1988. Biogeographical notes on the genus Terebra (Gastropoda) at Isla del Coco, Costa Rica. Rev. Biol. Trop. 36: 569-574. (Bg, MoG)

423. Montoya, M. \& F. López-Pozuelo. 2007. Observaciones ornitológicas en la Isla del Coco, Costa Rica (marzo-Agosto 2007). Zeledonia 11: 1-11. (Av, Eg)

424. Montoya, M. \& M. Pascal 2004. Dos nuevos registros para la avifauna de la Isla del Coco, Costa Rica. Zeledonia 8: 7-11. (Av, Bd)

425. Morales-Ramírez, A. 2008. Caracterización cualitativa del zooplancton del Área de Conservación Marina Isla del Coco (ACMIC), Océano Pacífico de 
Costa Rica. Rev. Biol. Trop. 56 (Supl. 2): 159-169. (Bd, Eg, PlZ, Qt, Sa)

426. Moran, D.A. \& A.I. Dittel. 1993. Anomura and Brachyuran crabs of Costa Rica: annotated list of species. Rev. Biol. Trop. 41: 599-617. (Bd, CrD)

427. Moreno-Díaz, M.L. 2012. Actividades socioeconómicas desarrolladas alrededor y en el Parque Nacional Isla del Coco (Costa Rica) y posibles efectos del cambio climático sobre ellas. Rev. Biol. Trop. 60 (Supl. 3): 113-129. (SE)

428. Motomura, H. 2004. New species of scorpionfish, Scorpaena cocosensis (Scorpaeniformes: Scorpaenidae) from the Cocos Islands, Costa Rica, eastern Pacific Ocean. Copeia 2004: 818-824. (Bd, PiA)

429. Motomura, H. \& J.E. McCosker. 2009. Second specimen of the Costa Rican scorpionfish, Scorpaena cocosensis (Scorpaenidae): the first record from the Galápagos Islands, with fresh color notes on this species. Biogeography 11: 135-137. (Bd, PiA)

430. Mulliner, D.K. 1993. Opisthobranchs of Cocos Island. West. Soc. Malac. Ann. Rep. [for 1992] 25: 2-3. (Bd, MoG)

431. Myers, B.W. 2000. New distribution record for Favartia (Murexiella) mildredae Poorman, 1980 (Gastropoda: Muricidae). Festivus 32: 9-10. (Bd, $\mathrm{MoG})$

432. Myers, B.W. \& A. D'Attilio. 1990. Three new muricacean species from Cocos Island, Costa Rica (Muricidae and Coralliophilidae). Venus 49: 281-292. (Bd, MoG)

433. Myers, G.S \& C.B. Wade. 1941. Four new genera and ten new species of eels from the Pacific Coast of tropical America. Allan Hancock Pac. Exp. 9:65-111. (Bd, PiA)

434. Nunomura, N. 1978. Tanaidaceans and anthuridean isopods collected on the Presidental Cruise of 1938. Proc. Biol. Soc. Washington 91: 936-952. (Bd, CrI, CRT)

435. O’Connor, J.M., P. Stoffers, J.R. Wijbrans \& T.J. Worthington. 2007. Migration of widespread longlived volcanism across the Galápagos Volcanic Province: evidence for a broad melting anomaly? Earth Planet. Sci. Lett. 263: 339-354. (Ge, Vu)

436. Olsson, A.A. 1956. Studies on the genus Olivella. Proc. Acad. Nat. Sci. Philadelphia 108: 155-225. (Bd, Eg, MoG)

437. Ornelas-Gatdula, E., Y. Camacho-García, M. Schrödl, V. Padula, Y. Hooker, T.M. Gosliner \& A. Valdés. 2012. Molecular systematics of the "Navanax aenigmaticus" species complex (Mollusca, Opisthobranchia): Coming full circle. Zool. Scripta. 41: 374-385.

438. Osburn, R.C. 1950. Bryozoa of the Pacific Coast of America. Part 1, Cheilostomata-Anasca. Allan Hancock Pac. Exped. 14: 1-269. (Bd, Br)
439. Osburn, R.C. 1952. Bryozoa of the Pacific Coast of America. Part 2, Cheilostomata-Ascophora. Allan Hancock Pac. Exped. 14: 271-611. (Bd, Br)

440. Osburn, R.C. 1953. Bryozoa of the Pacific Coast of America. Part 3, Cyclostomata, Ctenostomata, Entoprocta, and Addenda. Allan Hancock Pac. Exped. 14: 613-725. (Bd, Br)

441. Pearse, J.S. 1968. Gametogenesis and reproduction in several abyssal and shallow water echinoderms of the Eastern Tropical Pacific. Stanford Oceanogr. Exp. Cruise 20, Te Vega Rep.: 225-234. (Bd, Ec, Eg, ZP)

442. Pennington, J.T., K.L. Mahoney, V.S. Kuwahara, D.D. Kolber, R. Callienes \& F.P. Chavez. 2006. Primary production in the eastern tropical Pacific: a review. Prog. Oceanogr. 69: 285-317. (PIF, PP)

443. Perger, R., R. Vargas \& A. Wall. 2011. Johngarthia cocoensis, a new species of Gecarcinidae MacLeay, 1838 (Crustacea, Decapoda, Brachyura) from Cocos Island, Costa Rica. Zootaxa 2911: 57-68. (Bd, CrD)

444. Pérez-Ruzafa A., J.J. Alvarado, F.A. Solís-Marín, J.C. Hernández, A. Morata, C. Marcos, M. Abreu-Pérez, O. Aguilera, J. Alió, J.J. Bacallado-Aránega, E. Barraza, M. Benavides-Serrato, F. Benítez-Villalobos, L. Betancourt-Fernández, M. Borges, M. Brandt, M.I. Brogger, G.H. Borrero-Pérez, B.E. Buitrón-Sánchez, L.S. Campos, J.R. Cantera, S. Clemente, M. CohenRenfijo, S.E. Coppard, L.V. Costa-Lotufo, R. del Valle-García, M.E. Díaz de Vivar, J.P. Díaz-Martínez, Y. Díaz, A. Durán-González, L. Epherra, M. Escolar, V. Francisco, C.A. Freire, J.E. García-Arrarás, D.G. Gil, P. Guarderas, V.F. Hadel, A. Hearn, E.A. HernándezDelgado, A. Herrera-Moreno, M.D. Herrero-Pérezrul, Y. Hooker, M.B.I. Honey-Escandón, C. Lodeiros, M. Luzuriaga, C.L.C. Manso, A. Martín, M.I. Martínez, S. Martínez, L. Moro-Abad, E. Mutschke, J.C. Navarro, R. Neira, N. Noriega, J.S. Palleiro-Nayar, A.F. Pérez, E. Prieto-Ríos, J. Reyes, R. RodríguezBarreras, T. Rubilar, T.I. Sancho-Mejías, C. Sangil, J.R.M.C. Silva, J.I. Sonnenholzner, C.R.R. Ventura, A. Tablado, Y. Tavares, C.G. Tiago, F. Tuya \& S.M. Williams. 2013. Chapter 16: Latin America echinoderm biodiversity and biogeography: patterns and affinities, p. 511-542. In J.J. Alvarado \& F.A. SolísMarín (eds.). Echinoderm Research and Diversity in Latin America. Springer, Berlin, Heidelberg. (Bd, $\mathrm{Bg}, \mathrm{Ec})$

445. Pilsbry, H.A. \& E.G. Vanatta. 1902. Papers from the Hopkins Stanford Galápagos Expedition, 1898-1899. XIII. Marine Mollusca. Proc. Washington Acad. Sci. 4: 549-560. (Bd, Mo)

446. Pitombo, F.B \& A. Ross. 2002. A checklist of the intertidal and shallow-water sessile barnacles of the eastern Pacific, Alaska to Chile, p. 97-107. In M.E. Hendrickx (ed.). Contributions to the Study of East Pacific Crustacea [Contribuciones al estudio de los 
crustáceos del Pacífico Este], Vol. 1, Inst. Cien. Mar Limnol., UNAM, México Df, México. (Bd, CrP)

447. Pittier, H.F. 1899. Apuntamientos preliminares sobre la Isla del Coco, posesión costarricense en el Océano Pacífico, p. 15-28. En: Reproducciones Científicas, una Expedición y Legislación de la Isla del Coco. Instituto Geográfico de Costa Rica, Ministerio de Transportes. San José, Costa Rica, 1963. (Ep)

448. Pittier, H.F. 1935. Apuntamientos preliminares sobre la Isla del Coco, posesión costarricense en el Océano Pacífico. Rev. Col. Sup. Señoritas 2(4-5): 2-11. (Ep)

449. Polidoro, B.A., T. Brooks, K.E. Carpenter, G.J. Edgar, S. Henderson, J. Sanciangco \& D.R. Robertson. 2012. Patterns of extinction risk and threat for marine vertebrates and habitat-forming species in the Tropical Eastern Pacific. Mar. Ecol. Prog. Ser. 448: 93-104. (Av, Cv, CnA, PiA, PiE, Mm, Rp)

450. Poss, S.G., J.E. McCosker \& C.C. Baldwin. 2010. A new species of Scorpaenodes (Pisces: Scorpaenidae) from the Galápagos and Cocos islands with discussions of the limits of Scorpaenodes and Thysanichthys. Proc. California Acad. Sci. 61: 235-267. (Bd, PiA)

451. Protti, E. 1964. Ensayo sobre el clima de la Isla del Coco. Inst. Geogr. Nac. Ser. Geogr. 2: 27-28. (CA)

452. Protti, M., V. González, J. Freymueller \& S. Doelger. 2012. Isla del Coco, on Cocos Plate, converges with San Andres Island, on the Caribbean Plate, at $78 \mathrm{~mm} /$ yr. Rev. Biol. Trop. 60 (Suppl. 3): 33-41. (Ge, TP)

453. Quirós-Badilla, E. \& E.J. Alfaro. 2009. Algunos aspectos relacionados con la variabilidad climática en la Isla del Coco, Costa Rica. Rev. Climat. 9: 33-44. (CA, VC)

454. Randall, J.E. \& J.E. McCosker. 1975. The eels of Easter Island with a description of a new moray. Contrib. Sci., Nat. Hist. Mus. Los Angeles County 264: 1-32. (Bd, PiA)

455. Rathbun, M.J. 1902. Papers from the Hopkins Stanford Galápagos Expedition, 1898-1899. VIII. Brachyura and Macrura. Proc. Washington Acad. Sci. 4: 275-292. (Bd, CrD)

456. Rathbun, M.J. 1930. The cancroid crabs of America of the families Euryalidae, Portunidae, Ateleeyelidae, Cancridae and Xanthidae. U.S. Natl. Mus. Bull. 152: I-XVI, 1-609. (Bd, CrD)

457. Rathbun, M.J. 1937. The Oxystomatous and allied crabs of America. U.S. Natl. Mus. Bull. 166: I-VI, 1-278. (Bd, CrD)

458. Raz-Guzmán, A. \& M. Hermoso. 2002. Distribución espacial y afinidades zoogeográficas de los camarones carideos y cangrejos anomuros y braquiuros de los sistemas litorales de Michoacán, p. 265-279. In M.E. Hendrickx (ed.). Contribuciones al estudio de los crustáceos del Pacífico Este [Contributions to the
Study of East Pacific Crustacea], Vol. 1, Inst. Cien. Mar Limnol., UNAM, México DF, México. (Bg, $\mathrm{CrD}, \mathrm{Eg})$

459. Reid, D.G. 1999. The genus Littoraria Griffith \& Pidgeon, 1834 (Gastropoda: Littorinidae) in the tropical eastern Pacific. Veliger 42: 21-53. (Bd, MoG)

460. Reid, D.G. 2002. The genus Nodilittorina von Martens, 1897 (Gastropoda: Littorinidae) in the eastern Pacific Ocean, with a discussion of Biogeographic Provinces of the rocky-shore fauna. Veliger 45: 85-170. (Bd, Bg, MoG)

461. Reid, D.G. \& K.L. Kaiser. 2001. Three new records of Indo-Pacific Littorinidae (Gastropoda) in the tropical eastern Pacific. Veliger 44: 381-388. (Bd, MoG)

462. Reiswig, H.M. 2010. A new species of Tretodictyum (Porifera: Hexactinellida: Tretodictyidae) from off Cocos Island, tropical eastern Pacific Ocean. Proc. Biol. Soc. Washington 123: 242-250. (Bd, Po)

463. Reyes, S. \& G. Vogel. 1981. Meteorological and climatological observations on Cocos Island. Rev. Geofís. 14/15: 85-93. (CA)

464. Robertson, D.R. \& K.L. Cramer. 2009. Shore fishes and biogeographic subdivisions of the Tropical Eastern Pacific. Mar. Ecol. Prog. Ser. 380: 1-17. (Bd, BG, PiA, PiE)

465. Robertson, D.R., J.S. Grove \& J.E. McCosker. 2004. Tropical transpacific shore fishes. Pac. Sci. 58: 507565. (Bg, PiA, PiE)

466. Robson, G.C. 1929. A monograph of the Recent Cephalopoda based on the collections in the British Museum (Natural History). Part 1. Octopodinae. Printed by order of the Trustees of the British Museum, July 27: 1-236. (Bd, MoC)

467. Robson, G.C. 1932. A monograph of the Recent Cephalopoda based on the collections in the British Museum (Natural History). Part 2. Octopoda. Printed by order of the Trustees of the British Museum, January 23: 1-359. (Bd, MoC)

468. Robson, G.C. 1948. The Cephalopoda Decapoda of the Arcturus Oceanographic Expedition, 1925. Zoologica 33: 115-132. (Bd, MoC)

469. Rodríguez-Fonseca, J. 2001. Diversidad y distribución de los cetáceos de Costa Rica (Cetacea: Delphinidae, Physeteridae, Ziphiidae y Balaenopteridae). Rev. Biol. Trop. 49 (Supl. 2): 135-143. (Bd, Bg, Mm)

470. Rodríguez-Sáenz, K. \& R. Gasca. 2009. Siphonophores. Texto: p. 151-156, Lista de especies, disco compacto: p. 101-104. In I.S. Wehrtmann and J. Cortés (eds.). Marine Biodiversity of Costa Rica, Central America. Springer, Berlin. (Bd, $\mathrm{CnH})$

471. Rodríguez-Sáenz, K. \& L. Segura-Puertas. 2009. Hydrozoa, Scyphozoa, and Cubozoa (Medusozoa). Texto: p. 143-149, Lista de especies, disco compacto: p. 94-100. In I.S. Wehrtmann \& J. Cortés (eds.). 
Marine Biodiversity of Costa Rica, Central America. Springer, Berlin. (Bd, $\mathrm{CnH}, \mathrm{CnM}$ )

472. Rodríguez-Sevilla, L., R. Vargas \& J. Cortés. 2009. Benthic, shelled gastropods. Texto: p. 333-355, Lista de especies, disco compacto: p. 243-325. In I.S. Wehrtmann \& J. Cortés (eds.). Marine Biodiversity of Costa Rica, Central America. Springer, Berlin. (Bd, MoG)

473. Rojas, W. \& G.E. Alvarado. 2012. Geología y contexto geotectónico de la Isla del Coco y la zona marítima frente al Pacífico central de Costa Rica. Rev. Biol. Trop. 60 (Suppl. 3): 15-32. (Ge, TP,Vu)

474. Rojas-Acuña, O.W. 1964. Informe general de las investigaciones realizadas en la Isla del Coco. Inst. Geogr. Nac. Ser. Geogr. 2: 21-26. (Hi, Inf)

475. Roper, C.F.E., M.J. Sweeney \& F.G. Hochberg. 1995. Cefalópodos, p. 305-353. In W. Fischer, F. Krupp, W. Schneider, C. Sommer, K.E. Carpenter \& V.H. Niem (eds.). Guía FAO para la identificación de especies para los fines de la pesca. Pacífico centro-oriental. Vol. 1. Plantas e invertebrados. FAO, Roma. (Bd, $\mathrm{Bg}, \mathrm{MoC})$

476. Rose, R. 1936. La Isla del Coco, leyenda de tesoro. Extracto del libro "The Arcturus Adventure" por WilliamBeebe, Traducción de don León Fernández Guardia. Rev. Col. Sup. Señoritas, Año III, Números 3 y 4: 44-55. (Ep, Hi)

477. Rosenblatt, R.H. \& B.W. Walter. 1963. The marine shore-fishes of the Galapagos Islands. Occ. Pap. California Acad. Sci. 44: 97-106. (Bd, PiA, PiE)

478. Rost, H. 1955. A report on the Family Arcidae (Pelecypoda). Allan Hancock Pac. Exped. 20: 177249. (Bd, MoB)

479. Roth, B. \& E.V. Coan. 1971. Marginellidae (Mollusca: Neogastropoda) from the Galápagos Islands and Cocos Island. Proc. California Acad. Sci. $4^{\text {th }}$ Ser. 37: 575-584. (Bd, MoG)

480. Rusch, D.B., A.L. Halpern, G. Sutton, K.B. Heidelberg, S. Williamson, S. Yooseph, D. Wu, J.A. Eisen, J.M. Hoffman, K. Remington, K. Beeson, B. Tran, H. Smith, H. Baden-Tillson, C. Stewart, J. Thorpe, J. Freeman, C. Andrews-Pfannkoch, J.E. Venter, K. Li, S. Kravitz, J.F. Heidelberg, T. Utterback, Y.-H. Rogers, L.I. Falcón, V. Souza, G. Bonilla-Rosso, L.E. Eguiarte, D.M. Karl, S. Sathyendranath, T. Platt, E. Bermingham, V. Gallardo, G. Tamayo-Castillo, M.R. Ferrari, R.L. Strausberg, K. Nealson, R. Friedman, M. Frazier, J.C. Venter. 2007. The Sorcerer II Global Ocean Sampling Expedition: Northwest Atlantic through Eastern Tropical Pacific. PLoS Biol. 5(3): e77. doi:10.1371/journal.pbio.0050077. (Bd, B\&A, $\mathrm{Gn})$

481. Salgado-Barragán, J. \& M.E. Hendrickx. 2010. Clave ilustrada para la identificación de los estomatópodos
(Crustacea: Hoplocarida) del Pacífico oriental. Rev. Mex. Biodiv. 81: S1- S49. (Bd, CrS)

482. Sasa, M., G.A. Chaves \& L.D. Patrick. 2009. Marine reptiles and amphibians. Texto: p. 459-468, Lista de especies, disco compacto: p. 474-478. In I.S. Wehrtmann \& J. Cortés (eds.). Marine Biodiversity of Costa Rica, Central America. Springer, Berlin. (Bd, Rp)

483. Schmitt, W.L. 1939. Decapod and other crustacea collected on the Presidential Cruise of 1938 (with introduction and station data). Smithsonian Mis. Col. 98 (6): 1-29. (Bd, CrD)

484. Schmitt, W.L. \& L.P. Schultz. 1940. List of the fishes taken on the Presidential Cruise of 1938. Smithsonian Mis. Col. 98 (25): 1-10. (Bd, PiA)

485. Schultz, L.P. 1944. A revision of the American clingfishes, Familia Gobiesocidae, with descriptions of new genera and forms. Proc. U.S. Nat. Mus. 96: 47-77. (Bd, PiA)

486. Schwabe, E. \& I.S. Wehrtmann. 2009. Chitons. Texto: p. 323-331, Lista de especies, disco compacto: p. 240-242. In I.S. Wehrtmann \& J. Cortés (eds.). Marine Biodiversity of Costa Rica, Central America. Springer, Berlin. (Bd, MoP)

487. Scott, P.H. 1993. New bivalves mollusks from Isla del Coco, Costa Rica. West. Soc. Malac., Ann. Rep. 1992. 25: 2. (Bd, MoB)

488. Seale, A. 1940. Report on fishes from Allan Hancock Expeditions in the California Academy of Sciences. Allan Hancock Pac. Exp. 9: 1-46. (Bd, PiA, PiE)

489. Senn, D.G. \& M. Glasstetter. 1989. On the occurrence of barnacle-reefs around Cocos Island, Costa Rica. Senkeberg. Mar. 20: 241-249. (Ar, CrP)

490. Setchell, W.A. 1937. The Templeton Crocker Expedition of the California Academy of Sciences, 1932. No. 34: Report on the Sargassum. Proc. Calif. Acad. Sci. 4th Ser. 22: 127-158. (Al, Bd)

491. Setchell, W.A. \& L.R. Mason. 1943. New or little known crustaceous corallines of Pacific North America. Proc. Natl. Acad. Sci. 29: 92-97. (Al, Bd)

492. Shasky, D.R. 1983. New records of Indo-Pacific Mollusca from Cocos Island, Costa Rica. Nautilus 97: 144-145. (Bd, Mo)

493. Shasky, D.R. 1983. Update on mollusk with IndoPacific faunal affinities in the tropical eastern Pacific II. Festivus 15: 109-110. (Bd, Mo)

494. Shasky, D.R. 1984. Redescription of Olivia foxi Stingley, 1984. Shells and Sea Life 16: 128-129. (Bd, MoG)

495. Shasky, D.R. 1984. Update on mollusk with IndoPacific faunal affinities in the tropical eastern Pacific III. Festivus 16: 123-124. (Bd, Mo) 
496. Shasky, D.R. 1985. Further notes on Cocos Island species. Hawaiian Shell News 33(9): 4. (Bd, Mo)

497. Shasky, D.R. 1986. Update on mollusks with IndoPacific faunal affinities in the tropical eastern Pacific IV. Festivus 18: 3-5. (Bd, Mo)

498. Shasky, D.R. 1987. Cantharus fragarius (Wood, 1828) at Cocos Island. Festivus 19: 30-31. (Bd, Mo)

499. Shasky, D.R. 1987. Update on mollusks with IndoPacific faunal affinities in the tropical eastern Pacific V. Festivus 19: 48-50. (Bd, Mo)

500. Shasky, D.R. 1987. Update on mollusks with IndoPacific faunal affinities in the tropical eastern Pacific VI. Festivus 19: 100-101. (Bd, Mo)

501. Shasky, D.R. 1988. Update on mollusks with IndoPacific faunal affinities in the tropical eastern Pacific VIII. Festivus 20: 104-105. (Bd, Mo)

502. Shasky, D.R. 1989. The Family Omalogyridae in the tropical eastern Pacific. Festivus 21: 17. (Bd, MoG)

503. Shasky, D.R. 1989. My last seven years - at Cocos Island. Festivus 21: 72-75. (Ep)

504. Shasky, D.R. 1996. Additional distribution records of interesting and rarely collected marine gastropods (Epitoniidae) from the tropical eastern Pacific. Festivus 28: 85-86. (Bd, Mo)

505. Shih, T.-t. \& E.A. Hendrycks. 2003. A new species and new records of the genus Vivilia Milne Edwards, 1830 (Amphipoda: Hyperiidea: Vibiliidae) occurring in the eastern Pacific Ocean. J. Nat. Hist. 37: 253296. (Bd, CrA)

506. Shoemaker, C.R. 1942. Amphipod crustaceans collected on the Presidencial Cruise of 1938. Smithsonian Mis. Coll. 101(11): 1-52. (Bd, CrA)

507. Shumway, G. 1954. Carnegie Ridge and Cocos Ridge in the east equatorial Pacific. J. Geol. 62: 573-586. (Ge)

508. Sibaja-Cordero, J.A. 2008. Tendencias espacio-temporales de los avistamientos de fauna marina en los buceos turísticos (Isla del Coco, Costa Rica). Rev. Biol. Trop. 56 (Suppl. 2): 113-132. (Ed, PiA, PiE, Rp)

509. Sibaja-Cordero, J.A. 2008. Vertical zonation in the rocky intertidal at Cocos Island (Isla del Coco), Costa Rica: A comparison with other tropical locations. Rev. Biol. Trop. 56 (Suppl. 2): 171-187. (Eg, ZR)

510. Sibaja-Cordero, J.A. 2009. Zonación vertical de organismos en los acantilados de la Isla del Coco, Costa Rica, p: 161-163. In J.S. Troncoso, I. Alejo \& J. López (eds.). Resúmenes II Simposio Internacional de Ciencias del Mar, 2009 (ISMS09), Vigo, España. $(\mathrm{Eg}, \mathrm{ZR})$

511. Sibaja-Cordero, J.A. \& J. Cortés. 2010. Comparación temporal de la composición y zonación de organismos en el intermareal rocoso del Parque Nacional Isla del Coco, Pacífico de Costa Rica. Rev. Biol. Trop. 58: 1387-1403. (Eg, ZR)

512. Sibaja-Cordero, J.A., J. Troncoso \& J. Cortés. 2012. The lancelet Asymmetron lucayanum complex in Cocos Island National Park, Pacific Costa Rica. Pac. Sci. 66: 521-526. (Ce)

513. Sibaja-Cordero, J.A., J.S. Troncoso, C. BenavidesVarela \& J. Cortés. 2012. Shallow water soft and hard bottoms of Isla del Coco National Park, Pacific Costa Rica. Rev. Biol. Trop. 60 (Suppl. 3): 53-66. (Mp, Sd)

514. Sibaja-Cordero, J.A., J. Cortés \& H.K. Dean. 2012. Depth diversity profile of polychates worms in Bahía Chatham, Isla del Coco National Park, Pacific of Costa Rica. Rev. Biol. Trop. 60 (Suppl. 3): 293-301. (Be, Eg, Py)

515. Skoglund, C. 1990. Additions to the Panamic Province chitons (Polyplacophora) literature, 1971 through 1988. Festivus 21 :78-91. (Bd, MoP)

516. Skoglund, C. 2000. Spondylus linguaefelis Sowerby, 1847 (Bivalvia: Spondylidae) in the Panamic Province, with notes on the occurrence of Spondylus nicobaricus Schreibers, 1793. Festivus 32: 3-7. (Bd, $\mathrm{Bg}, \mathrm{MoB})$

517. Skoglund, C. 2001. Panamic Province Molluscan Literature. Additions and changes from 1971 through 2000. I. Bivalvia. Festivus 32 (Supplement): 119 p. $(\mathrm{Bd}, \mathrm{MoB})$

518. Skoglund, C. 2001. Panamic Province Molluscan Literature. Additions and changes from 1971 through 2000. II Polyplacophora. Festivus 32 (Supplement): 20 p. (Bd, MoP)

519. Skoglund, C. 2002. Panamic Province Molluscan Literature. Additions and changes from 1971 through 2001. III Gastropoda. Festivus 33 (Supplement): 286 p. $(\mathrm{Bd}, \mathrm{MoG})$

520. Slevin, J.R. 1931. Log of the shooner Academy on a voyage of scientific research to the Galapagos Island., 1905-1906. California Acad. Sci., Occ. Paper 17: 1-162. (Ep)

521. Slud, P. 1967. The birds of Cocos Island [Costa Rica]. Bull. Amer. Mus. Nat. Hist. 134: 261-296. (Av, Bd)

522. Snodgrass. R.E. \& E. Heller. 1902. The birds of Clipperton and Cocos Island. Proc. Washington Acad. Sci. 4: 501-520. (Av, Bd)

523. Snodgrass, R.E. \& E. Heller. 1905. Papers from the Hopkins-Stanford Galapagos Expedition, 1898-1899. XVII. Shore fishes of the Revillagigedo, Clipperton, Cocos and Galapagos islands. Proc. Washington Acad. Sci. 6: 333-427. (Bd, PiA, PiE)

524. Soot-Ryen, T. 1955. A report on the Family Mytilidae (Pelecypoda). Allan Hancock Pac. Exped. 20: 1-175. (Bd, MoB) 
525. Sphon, G.G., Jr. 1961. Notes on the Mitridae of the eastern Pacific. 1- Mitra fultoni E.A. Smith. Veliger 4: 32-36. (Bd, MoG)

526. Springer, M. 2009. Marine insects. Texto: p. 313-322, Lista de especies, disco compacto: p. 239. In I.S. Wehrtmann \& J. Cortés (eds.). Marine Biodiversity of Costa Rica, Central America. Springer, Berlin. (Bd, IM)

527. Starr, R.M., J. Cortés, C.L. Barnes, K. Green \& O. Breedy. 2012. Characterization of deepwater invertebrates at Isla del Coco National Park and Las Gemelas Seamounts, Costa Rica. Rev. Biol. Trop. 60 (Suppl. 3): 303-319. (Eg, , MS, ZP)

528. Starr, R.M., K. Green \& E. Sala. 2012. Deepwater fish assemblages at Isla del Coco National Park and Las Gemelas Seamounts, Costa Rica. Rev. Biol. Trop. 60 (Suppl. 3): 347-362. (Eg, PiA, PiE, MS, ZP)

529. Stebbing, T.R.R. 1903. Amphipoda from Costa Rica Proc. U.S. Natl. Mus. 26(1341): 925-931. (Bd, CrA)

530. Stiles, G., Skutch, A.F \& D. Gardner. 1988. A Guide to the Birds of Costa Rica. Cornell Univ. Press, Ithaca, New York. 551 p. (Av, Bd)

531. Stingley, D.V. 1984. A new Olivia from the eastern Pacific (Gastropoda: Olividae). Conchiglia 16 (178179): 28. (Bd, MoG)

532. Strong, A.M. \& H.N. Lowe. 1936. West American species of the genus Phos. Trans. San Diego Soc. Nat. Hist. 8: 305-320. (Bd, MoB)

533. Studer, T. 1894. Reports on the dredging operations off the west coasts of Central America to the Galapagos, to the west coast of Mexico, and in the Gulf of California, in charge of Alexander Agassiz, carried on by the U.S. Fish Commission Steamer "Albatross", during 1891, Lieut. Commander Z.L. Tanner, U.S.N., commanding. X. Note préliminaire sur les Alcyonaires. Bull. Mus. Comp. Zoöl. Harvard Coll. XXV: 53-69. (Bd, CnA)

534. Suárez-Morales, E. \& R. Gasca. 2012. A new Lepeophtheirus (Copepoda: Siphonostomatoida: Caligidae) from Isla del Coco, Costa Rica, Eastern Tropical Pacific. Rev. Biol. Trop. 60 (Suppl. 3): 235242. (Bd, CrC, PpC)

535. Suárez-Morales, E. \& A. Morales-Ramírez. 2009. New species of Monstrilloida (Crustacea: Copepoda) from the Eastern Tropical Pacific. J. Nat. Hist. 43: 1257-1271. (Bd, CrC)

536. Taylor, W.R. 1945. Pacific marine algae of the Allan Hancock Expeditions to the Galapagos Islands. Allan Hancock Pac. Exp. 12: 1-528. (Av, Bd)

537. Tee-Van, J. 1926. The Arcturus: Equipment and operation. Zoologica 8: 47-106. (Ep)

538. Thoma, B.P., R.W. Heard, R. Vargas. 2005. A new species of Parapinnixa (Decapoda: Brachyura:
Pinnotheridae) from Isla del Coco, Costa Rica. Proc. Biol. Soc. Washington 118: 543-550. (Bd, CrD)

539. Tomlin, J.R. Le B. 1927. The Mollusca of the 'St. George' expedition (I). The Pacific coast of S. America. J. Conchol. 18: 153-170. (Bd, Mo)

540. Tomlin, J.R. 1928. The Mollusca of the "St George" expedition. II. The Pacific coast of South America. J. Conchol. 18: 187-198. (Bd, Mo)

541. Tovar-Hernández, M.A. \& H. Dean. 2010. Four new species of fan worms (Polychaeta: Sabellidae) from worldwide localities. Sci. Mar. 74: 815-826. (Bd, Py)

542. Townsend, C.H. 1901. Dredging and other records of the United States Fish Commission Steamer Albatross, with bibliography relative to the work of the vessel. U.S. Fish. Comm. Rep. 1900: 387-562. (Bb, Ep)

543. Treadwell, A.L. 1928. Polychaetous annelids from the Arcturus Oceanographic Expedition. Zoologica 8: 449-485. (Bd, Py)

544. Tsuchiya, M. 1974. Variation of the surface geostropic flow in the eastern intertropical Pacific Ocean. Fish. Bull. 72: 1075-1086. (OF)

545. Turner, R.D. \& K.J. Boss. 1962. The genus Lithophaga in the western Atlantic. Johnsonia 4: 81-116. $(\mathrm{Bd}, \mathrm{MoB})$

546. Valdés, Á. \& Y.E. Camacho-García. 2004. "Cephalaspidean" Heterobranchs (Gastropoda) from the Pacific Coast of Costa Rica. Proc. California Acad. Sci. 55: 459-497. (Bd, MoG)

547. Van der Heiden, A.M. \& R. Mitchell. 1998. Rediscovery and description of the flounder Syacium maculiferum (Garman, 1899): An endemic species of Cocos Island, Costa Rica (Pleuronectiformes : Paralichthyidae). Copeia 1998 : 753-758. Bd, PiA

548. Van Syoc, R. 2009. Barnacles. Texto: p. 283-289, Lista de especies, disco compacto: p. 219-223. In I.S. Wehrtmann \& J. Cortés (eds.). Marine Biodiversity of Costa Rica, Central America. Springer, Berlin. $(\mathrm{Bd}, \mathrm{CrP})$

549. Vargas, J.A. \& H.K. Dean. 2009. Sipunculans. Texto: p. 175-180, Lista de especies, disco compacto: p. 119-121. In I.S. Wehrtmann \& J. Cortés (eds.). Marine Biodiversity of Costa Rica, Central America. Springer, Berlin. (Bd, Si)

550. Vargas, R. 2009. Stomatopods. Texto: p. 193-197, Lista de especies, disco compacto: p. 160-163. In I.S. Wehrtmann \& J. Cortés (eds.). Marine Biodiversity of Costa Rica, Central America. Springer, Berlin. (Bd, CrS)

551. Vargas, R. \& J. Cortés. 1997. Biodiversidad marina de Costa Rica: Orden Stomatopoda (Crustacea: Hoplocarida). Rev. Biol. Trop. 45: 1531-1539. (Bd, $\mathrm{CrS})$ 
552. Vargas, R. \& J. Cortés. 1999. Biodiversidad marina de Costa Rica: Crustacea: Decapoda (Penaeoidea, Sergestoidea, Caridea, Astacidea, Thalassinidea, Palinura) del Pacífico. Rev. Biol. Trop. 47: 887-911. (Bd, $\mathrm{CrD})$

553. Vargas, R. \& J. Cortés. 2006. Biodiversidad marina de Costa Rica: Crustacea: Infraorden Anomura. Rev. Biol. Trop. 54: 461-488. (Bd, CrD)

554. Vargas-Castillo, R. \& I.S. Wehrtmann. 2008. Stomatopods and decapods from Isla del Coco, Pacific Costa Rica. Rev. Biol. Trop. 56 (Suppl. 2): 79-97. $(\mathrm{Bd}, \mathrm{CrD}, \mathrm{CrS})$

555. Vargas, R. \& I.S. Wehrtmann. 2009. Decapod crustaceans. Texto: p. 209-228, Lista de especies, disco compacto: p. 167-198. In I.S. Wehrtmann \& J. Cortés (eds.). Marine Biodiversity of Costa Rica, Central America. Springer, Berlin. (Bd, CrD)

556. Vargas, S., H.M. Guzmán \& O. Breedy. 2008. Distribution patterns of the genus Pacifigorgia (Octocorallia: Gorgoniidae): track compatibility analysis and parsimony analysis of endemicity. J. Biogeogr. 35: 241-247. (Bd, Bg, CnA)

557. Vargas, S., O. Breedy \& H.M. Guzman. 2010. The phylogeny of Pacifigorgia (Coelenterata, Octocorallia, Gorgoniidae): a case study of the use of continuous characters in the systematics of the Octocorallia. Zoosystema 32: 5-18. (Bd, CnA, Gn)

558. Vargas-Montero, M., Á. Morales-Ramírez \& J. Cortés. 2012. Primer informe del género Gambierdiscus (Dinophyceae) en el Parque Nacional Isla del Coco, Pacífico Tropical Oriental. Rev. Biol. Trop. 60 (Supl. 3): 187-199. (Bd, Di)

559. Venegas, J. 1982. Un viejo nombre y una isla. Inst. Geogr. Nac., San José, Costa Rica. Inf. Semestral (Julio-Dic. 1982): 10-15. (Hi)

560. Villalobos-Rojas, F., Y.E. Camacho-García \& A.G. Guzmán-Mora. 2008. Catalogue of the type material of mollusks deposited at the Zoology Museum, University of Costa Rica. Nautilus 122: 155-165. (Bd, $\mathrm{Co}, \mathrm{Mo})$

561. Vermeij, G.J. \& M.A. Snyder. 2002. Leucozonia and related genera of Fasciolariid gastropods: Shell-based taxonomy and relationships. Proc. Acad. Nat. Sci. Philadelfia 152: 23-44. (Bd, MoG)

562. Vogler, C., J. Benzie, H. Lessios, P. Barber \& G. Wörheide. 2008. A threat to coral reefs multiplied? Four species of crown-of-thorns starfish. Biol. Lett. 4: 696-699. (Ar, EcA, Gn)

563. Vokes, E.H. 1980. Review of the muricid genus Acanthotrophon (Mollusca: Gastropoda). Veliger 23: 10-14. (Bd, MoG)

564. Waller, T.R. 2007. The evolutionary and biogeographic origins of the endemic Pectinidae (Mollusca:
Bivalvia) of the Galapagos Islands. J. Paleontol. 81: 929-950. (Bd, Bg, Ev, Gn, MoB)

565. Walton, B.C. 1954. The genus Pylopagurus (Crustacea: Anomura) in the Pacific with descriptions of two new species. Allan Hancock Pac. Exp. 18: 139-173. $(\mathrm{Bd}, \mathrm{CrD})$

566. Wang, C. \& P. Fiedler. 2006. ENSO variability in the eastern tropical Pacific: a review. Prog. Oceanogr. 69: 239-266. (ENSO)

567. Warén, A. 1992. Comments on and descriptions of eulimid gastropods from tropical west America. Veliger 35: 177-194. (Bd, MoG)

568. Wehrtmann, I.S., J. Cortés \& S. Echeverría-Sáenz. 2009. Marine biodiversity of Costa Rica: perspectives and conclusions, p. 521-533. In I.S. Wehrtmann and J. Cortés (eds.). Marine Biodiversity of Costa Rica, Central America. Springer, Berlin. (Bd)

569. Werner, R., K. Hoernle, P. van den Bogaard, C. Ranero \& R. von Huene. 1999. Drowned 14 m.y.-old Galápagos archipielago off the coast of Costa Rica: Implications for tectonic and evolutionary models. Geology 27: 499-502. (Ev, Ge, TP)

570. Werner, R., K. Hoernle, U. Barckhausen \& F. Hauff. 2003. Geodynamic evolution of the Galápagos hot spot system (Central East Pacific) over the past 20 m.y.: constraints from morphology, geochemistry, and magnetic anomalies. Geochem. Geophys. Geosyst. 4 (12), 1108, doi: 10.1029/2003GC000576. (Ge, TP)

571. Whitney, N.M. \& P.J. Motta. 2008. Cleaner host posing behavior of whitetip reef sharks (Triaenodon obesus) in a swarm of hyperiid amphipods. Coral Reefs (Reef Site) 27: 363. (Cm, CrA, Eg, PiE)

572. Whitney, N.M., H.L. Pratt \& J.C. Carrier. 2004. Group courtship, mating behaviour and siphon sac function in the whitetip reef shark, Triaenodon obesus. Animal Behav. 68: 1435-1442. (Eg, PiE)

573. Wicksten, M.K. 1981. New records of Steromastis sculpta pacifica (Faxon) (Decapoda: Polychelidae) in the eastern Pacific Ocean. Proc. Biol. Soc. Washington 93: 914-919. (Bd, Bg, CrD)

574. Wicksten, M.K. 1983. Shallow water caridean shrimps of the Gulf of California, México. Allan Hancock Monogr. Mar. Biol. 13: 1-59. (Bd, CrD)

575. Wicksten, M.K. 1989. A key to the penaeoid shrimp of the eastern Pacific region. Bull. South. Calif. Acad. Sci. 88: 11-20. (Bd, CrD)

576. Wicksten, M.K. 1990. Key to the hippolytid shrimp of the eastern Pacific Ocean. Fish. Bull. 88: 587-598. $(\mathrm{Bd}, \mathrm{CrD})$

577. Wicksten, M.K. \& M.E. Hendrickx. 1992. Checklist of Penaeoid and Caridean shrimps (Decapoda: Penaeoidea, Caridea) from the eastern tropical Pacific. Proc. San Diego Soc. Nat. Hist. 9: 1-11. (Bd, CrD) 
578. Wicksten, M.K. \& M.E. Hendrickx. 1992. An updated checklist of benthic marine and brackish water shrimps (Decapoda: Penaeoidea, Stenopodidea, Caridea) from the Eastern Tropical Pacific, p. 49-76. In M.E. Hendrickx (ed.). Contributions to the Study of East Pacific Crustaceans, 2. [Contribuciones al estudio de los Crustáceos del Pacífico Este, 2]. Instituto de Ciencias del Mar y Limnología, UNAM, México DF, México. (Bd, CrD)

579. Wicksten, M.K. \& R. Vargas. 2001. A new species of Thor Kingsley, 1878 (Crustacea: Decapoda: Caridea: Hippolytidae) from the tropical eastern Pacific. Proc. Biol. Soc. Washington 114: 139-144. (Bd, CrD)

580. Willett, C.S., R.R. Leben \& M.F. Lavín. 2006. Eddies and Tropical Instability Waves in the eastern tropical Pacific: A review. Prog. Oceanogr. 69: 218-238. (OF)

581. Williams, A.B. 1986. Mud shrimps, Upogebia, from the eastern Pacific (Thalassinoidea: Upogebiidae). San Diego Soc. Nat. Hist. Mem. 14: 1-60. (Bd, CrD)

582. Williams, G.C. \& O. Breedy. 2004. The Panamic Gorgonian genus Pacifigorgia (Octocorallia: Gorgoniidae) in the Galápagos Archipelago, with descriptions of three new species. Proc. California Acad. Sci. 55: 55-88. (Bd, CnA)

583. Williamson, S.J., D.B. Rusch, S. Yooseph, A.L. Halpern, K.B. Heidelberg, J.I. Glass, C. AndrewsPfannkoch, D. Fadrosh, C.S. Miller, G. Sutton, M. Frazier, J.C. Venter. 2008. The Sorcerer II Global Ocean Sampling Expedition: Metagenomic characterization of viruses within aquatic microbial samples. PLoS ONE 3(1): e1456. doi:10.1371/journal. pone.0001456. (Bd, Gn, Vi)

584. Wilson, D.S. 1996. Fastest known spreading on the Miocene Cocos-Pacific Plate boundary. Geophys. Res. Lett. 23: 3003-3006. (Ge, TM)

585. Wilson, H.V. 1904. Reports on an exploration off the west coasts of Mexico, Central and South America, and off the Galapagos Islands, in charge of Alexander Agassiz, by the U.S. Fish Commission Steamer Albatross, during 1891, Lieut. Commander Z.L. Tanner U.S.N., commanding. XXX. The sponges. Mem. Mus. Comp. Zoöl. Harvard Coll. XXX: 1-164. (Bd, Po)

586. Wyrtki, K. 1965. Surface currents of the eastern tropical Pacific Ocean. Inter-Amer. Trop. Tuna Comm. Bull. 9: 271-304. (OF)

587. Wyrtki, K. 1966. Oceanography of the eastern equatorial Pacific Ocean. Oceanogr. Mar. Biol. Ann. Rev. 4: 33-68. (OF)

588. Wyrtki, K. 1967. Circulation and water masses in the eastern equatorial Pacific Ocean. Int. J. Oceanol. Limnol. 1: 117-147. (OF)
589. Wyrtki, K. 2002. Reflections on my knowledge in the Indo-Pacific, pp. 53-57. In K.R. Benson \& P.F. Rehbock (eds.). Oceanographic History: the Pacific and Beyond. Proc 5th Int. Congr. Hist. Oceanogr. La Jolla, 1993. Univ. Washington Press, Seattle, Washington. (Hi, OF)

590. Young, B.E., K. Easley, R. Garrigues, B. Mactavish, P. Murgatroyd \& J.R. Zook. 2010. Swallow-tailed Gull Creagrus furcatus in Costa Rica. Cotinga 32: 24-26. (Av, Bd, Bg)

591. Zanella, I., A. López-Garro, G. Golfín-Duarte \& J.C. Sáenz. 2012. Biología del tiburón punta blanca de arrecife, Triaenodon obesus (Carcharhiniformes: Carcharhinidae), en Bahía Chatham, Parque Nacional Isla del Coco, Costa Rica. Rev. Biol. Trop. 60 (Suppl. 3): 339-346. (Eg, PiE)

592. Zapata, F.A, \& D.R. Robertson. 2007. How many species of shore fishes are there in the Tropical Eastern Pacific? J. Biogeogr. 34: 38-51. (Bd, Bg, PiA, PiE)

593. Ziesenhenne, F.C. 1937. The Templeton Crocker Expedition, X. Echinoderms from the West Coast of Lower California, the Gulf of California and Clarion Island. Zoologica 22: 209-239. (Bd, Ec)

594. Ziesenhenne, F.C. 1940. New ophiurans of the Allan Hancock Pacific Expeditions. Allan Hancock Pac. Exped. 8: 9-59. (Bd, EcO)

595. Ziesenhenne, F.C. 1942. New eastern Pacific sea stars. Allan Hancock Pac. Exped. 8: 197-223. (Bd, EcA)

596. Ziesenhenne, F.C. 1955. A review of the genus Ophioderma. Essays in the Natural Sciences in honor of Captain Allan Hancock on the occasion of his birthday, July 26, 1955. University of Southern California Press, Los Angeles, pp. 185-201. (Bd, EcO)

597. Zigler, K.S \& H.A. Lessios. 2003. Evolution of bindin in the pantropical sea urchin Tripneustes: comparisons to bindin of other genera. Mol. Biol. Evol. 20: 220-231. (EcE, Ev, Gn)

598. Zimmerman, T.L. \& J.W. Martin. 1999. Brachyuran crabs of Cocos Island (Isla del Coco), Costa Rica: Leucosiidae, Calappidae, and Parthenopidae, with descriptions of two new species. J. Crust. Biol. 19: 643-668. (Bd, CrD)

599. Zullo, V.A. 1991. Zoogeography of the shallowwater cirriped fauna of the Galápagos Islands and the adjacent regions in the tropical eastern Pacific, p. 173-192. In M.J. James (ed.). Galápagos Marine Invertebrates: Taxonomy, Biogeography, and Evolution in Darwin's Islands. Plenum Press, New York and London. (Bd, Bg, CrD) 


\section{TESIS Y LIBROS SOBRE \\ INVESTIGACIONES MARINAS, GEOLÓGICAS Y ATMOSFÉRICAS EN EL PARQUE NACIONAL ISLA DEL COCO, COSTA RICA}

1. Allen, G.R. \& D.R. Robertson. 1994. Fishes of the Tropical Eastern Pacific. Univ. Hawaii Press, Honolulu, Hawai'i. 332 p. (Bd, Li, PiA, PiE)

2. Alvarado, G.E. 1984. Aspectos petrológicos-geológicos de los volcanes y unidades lávicas del Cenozoico Superior de Costa Rica. Tesis de Licenciatura, Escuela Centroamericana de Geología, Universidad de Costa Rica, San Pedro, Costa Rica. 183 p. (Ge, $\mathrm{Te}, \mathrm{Vu})$

3. Alvarado, G.E. 1989. Los volcanes de Costa Rica. EUNED, San José, Costa Rica. 175 p. (Ge, Li, Vu)

4. Alvarado, G.E. 1993. Costa Rica: Land of Volcanoes. Gallo Pinto Press, San José, Costa Rica. 181 p. (Ge, $\mathrm{Li}, \mathrm{Vu}$ )

5. Alvarado, G.E. 2000. Los volcanes de Costa Rica: $\mathrm{Su}$ geología, historia y riqueza natural ( $2^{\text {da }}$ edic.). EUNED, San José, Costa Rica. 269 p. (Ge, Hi, Li, $\mathrm{Vu})$

6. Alvarado, G.E. 2009. Los volcanes de Costa Rica: Geología, historia, riqueza natural y su gente $\left(3^{\text {da }}\right.$ edic.). EUNED, San José, Costa Rica. 335 p. (Ge, $\mathrm{Hi}, \mathrm{Li}, \mathrm{Vu}$ )

7. Alvarado-Barrientos, J.J. 2012. Estado e impacto de Diadema mexicanum A. Agassiz, 1863 (Echinoidea) en los arrecifes coralinos del Pacífico Tropical Oriental. Disertación doctoral, Posgrado en Ciencias Marinas y Costeras, Universidad Autónoma de Baja California Sur, La Paz, Baja California Sur, México. 192 p. (Bi, EcE, Eg, Te)

8. Alvarado-Induni, G.E. 2005. Costa Rica: Land of Volcanoes. EUNED, San José, Costa Rica. 309 p. (Ge, Li, Vu)

9. Arias, R., 1990. Isla del Coco, Historia y Leyenda. Tesis Licenciatura en Historia, Universidad de Costa Rica, San Pedro, San José, Costa Rica. 294 p. (Hi, Te)

10. Beebe, W. 1926. The Arcturus Adventure: An Account of the New York Zoological Society's First Oceanographic Expedition. G.P. Putman's Sons, New York. 439 p. (Re-impreso en 1981 por Harper Colophon Books, New York). (Ep, Hi, Li)

11. Bergoeing, J. P., 1998. Geomorfología de Costa Rica. Instituto Geográfico Nacional, San José, Costa Rica. 423 p. (Go, Li)

12. Bradley, G.E. \& J. Ireland. 193. Such is Life in Costa Rica: Underwater. Printex Int., San José, Costa Rica. 95 p. (Bd)
13. Bundschuh, J. \& G.E. Alvarado (eds.) 2007. Central America: Geology, Resources and Hazards. Taylor \& Francis, Londres/London. Vol. 1 + 2: 1311 p. (Ge, $\mathrm{Gg}, \mathrm{Li})$

14. Burgess, C.M. 1970. The Living Cowries. A.S. Barnes and Company. Crambury, New Jersey. 389 p. (Bd, Li, MoG)

15. Burgess, C.M. 1985. Cowries of the World. Gordon Verhoef Publ., Cape Town, South Africa. 289 p. (Bd, $\mathrm{Li}, \mathrm{MoG})$

16. Camhi, M.D., S.V. Valenti, S.V. Fordham, S.L. Fowler \& C. Gibson. 2009. The Conservation Status of Pelagic Sharks and Rays: Report of the IUCN Shark Specialist Group Pelagic Shark Red List Workshop. IUCN Species Survival Commission Shark Specialist Group. Newbury, U.K. 78 p. (Cv, Inf, PiE)

17. Cortés, J. (ed.). 2008. Investigaciones marinas en la Isla del Coco, Costa Rica / Marine Research at Isla del Coco (Cocos Island), Costa Rica / Recherches marines à l'Ile du Coco, Costa Rica. Revista de Biología Tropical, Volumen 56, Suplemento 2: 217 p. (VE)

18. Cortés, J., A. Morales, E. Alfaro, O. Lizano y J. Acuña. 2010. Conocimiento y gestión de medios marinos y coralinos del Área de Conservación Marina Isla del Coco. Sistema Nacional de Áreas de Conservación (SINAC), Ministerio de Ambiente, Energía y Telecomunicaciones (MINAET), en colaboración con Fondo Francés para el Medio Ambiente Mundial (FFMAM), The Global Environment Facility (GEF) y el Programa de las Naciones Unidas para el Desarrollo (PNUD). 21 p. (Bd, CA, Inf, Of, OQ, PlF, PlZ)

19. Crane, J. 1975. Fiddler Crabs of the World. Ocypodidae: Genus Uca. Princeton Univ. Press, Princeton, New Jersey. 738 p. (Bd, CrD, Li)

20. Fernández-García, C. 2012. Taxonomía y biogeografía de las familias Caulerpaceae (Chlorophyta), Dictyotaceae (Ochrophyta) y Corallinaceae (Rhodophyta) en el Pacífico de Centroamérica. Disertación doctoral, Posgrado en Ciencias Marinas y Costeras con orientación en Biología Marina, Universidad Autónoma de Baja California Sur, La Paz, Baja California Sur, México. 253 p. (Al, Bd, Te)

21. Fernández-Leiva, S. 1996. Taxonomía del ictioplancton en la Isla del Coco, Costa Rica. Tesis Licenciatura Biología, Universidad de Costa Rica, San Pedro, Costa Rica. 175 p. (Bd, PiA, PlZ, Te)

22. Fiedler, P.C. \& M.F. Lavín (Eds). 2006. A Review of Eastern Tropical Pacific Oceanography. Prog. Oceangr. 69 (2-4): 91-398. (OF, VE)

23. Garrison, G. 2005. Peces de la Isla del Coco/Isla del Coco Fishes, 2nd ed. Edit. INBio, Heredia, Costa Rica. 429 p. (Bd, Li, PiA, PiE, Rp) 
24. Graziano, L. 2001. Cruise Report S-177, Scientific Activities Undertaken Aboard SSV Robert C, Seamans, San Diego, California-Puntarenas, Costa Rica, October 10, 2001-November 18, 2001. Sea Education Association, Woods Hole, Massachusetts. 45 p. (Ep)

25. Grove, J.S. \& R.J. Lavenberg. 1997. The Fishes of the Galapagos Islands. Stanford Univ. Press, Stanford, California, E.U.A. 863 p. (Bd, PiA, PiE)

26. Guido, A. 1935. Expedición a la Isla del Coco, Febrero de 1905-Diario de un viaje. Rev. Col. Sup. Señoritas, Año II, Números 4 y 5: 17-26. (Publicado por primera vez en febrero 1905, como "Diario de un viaje”, Imp. El Pacífico, Puntarenas) (Ep, Hi, Inf)

27. Hendrickx, M.E. \& F.D. Estrada-Navarrete. 1996. Los camarones pelágicos (Crustacea: Dendrobranchiata y Caridea) del Pacífico Mexicano. Comisión Nacional para el Conocimiento y Uso de la Biodiversidad e Inst. Cienc. Mar Limnol., UNAM. 157 p. (Bd, $\mathrm{CrD}, \mathrm{Li})$

28. Lockwood, J.P. \& B.T. Benumof. 2000. Investigaciones de las cuevas marinas de la isla del Coco. Datos de campo. Informe Puffin Invest. Co. Inc., 43 p. (Go, Inf)

29. Meredith, D.W. 1939. Voyages of the Velero III, a pictorial version with historical background of scientific expeditions through tropical seas to equatorial lands aboard M/V Velero III. Bookhaven Press, Los Angeles. 294 p. (Hi, Li)

30. Ministerio de Transportes, Instituto Geográfico Nacional (Costa Rica). 1963. Reproducciones científicas, una expedición y legislación de la Isla del Coco. San José, Costa Rica. 126 p. (Ep, Hi, Inf)

31. Montoya, M. 2007. Conozca la Isla del Coco. Una guía para su visitación: pp. 35-176. In BioCursos para amantes de la Naturaleza. Conozca el Parque Nacional Isla del Coco. La Isla del Tesoro (29 abril al 6 de mayo 2007). Organización para Estudios Tropicales (OET), San José, Costa Rica. (Bd, Go, Hi, Li)

32. Pacheco-Urpí, O., D. Ballestero-Sakson, L.M. SierraSierra, R. Jiménez-Montealegre, R. Quesada-Céspedes \& E. Acevedo-Trejos. 2008. Propuesta para la conservación de la zona marina adyacente al Parque Nacional Isla del Coco. Informe Contrato FUNDAUNA - FAICO 005-2007. Universidad Nacional, Heredia, Costa Rica. 129 p. (Cv, Inf)

33. Passmore, R.Mc.C. 1895. Informe sobre la Isla del Coco. In Reproducciones Científicas, Una Expedición y Legislación de la Isla del Coco. Inst. Geog. Nac., San José Costa Rica. 1963: 7-12. (Ep, Mp)

34. Petuch, E.J. \& D.M. Sargent. 1986. Atlas of the Living Olive Shells of the World. Coastal Education and Research Foundation, Jacksonville. 253 p. (Bd, $\mathrm{Li}, \mathrm{MoG})$
35. Reid, D.G. 1996. Systematics and Evolution of Littorina. Dorset Press, Great Britain. 463 p. (Bd, $\mathrm{Ev}, \mathrm{Ld}, \mathrm{MoG}$ )

36. Robertson, D.R. \& G.R. Allen. 2008. Shorefishes of the Tropical Eastern Pacific online information system. Version 1.0. Smithsonian Tropical Research Institute, Balboa, Panamá. www.neotropicalfishes. org/sftep, www.stri.org/sftep (Bd, PiA, PiE)

37. Rojas, R. \& I. Zanella (eds.). 2006. Memoria: Primer Seminario Taller sobre el estado del conocimiento de la Condrictiofauna de Costa Rica. INBio, Santo Domingo, Heredia, Costa Rica. (Eg, PiE, Sm)

38. Solano-Barquero, A. 2011. Macrofauna asociada a rodolitos en el Parque Nacional Isla del Coco, Costa Rica. Licenciatura en Biología con énfasis en Zoología, Universidad de Costa Rica, San Pedro, Costa Rica. 50 p. (Bd, Ro, Te)

39. Solórzano, A. 2004. Serpientes de Costa Rica: distribución, taxonomía e historia natural. Edit. INBio, Santo Domingo de Heredia, Costa Rica. 791 p. (Bd, Li, Rp)

40. Tournon, J. \& G.E. Alvarado. 1997. Carte géologique du Costa Rica: notice explicative; Mapa geológico de Costa Rica: folleto explicativo, échelle-escala 1500 000. Ed. Tecnol. Costa Rica, 80 p. + Mapa geológico de Costa Rica. (Ge, Li, Mp)

41. Weston, C., 1992: La isla del Coco/Cocos Island. Trejos Hnos. Sucesores S.A., San José, Costa Rica. 311 p. (Hi, Li)

\section{LIBROS HISTÓRICOS EN QUE SE MENCIONAN AMBIENTES Y ORGANISMOS MARINOS DE LA ISLA DEL COCO}

1. Belcher, E. 1843. Narrative of a Voyage Round the World, Performed in Her Majesty's Ship Sulphur during the Years 1836-1842, Including Details of the Naval Operations in China, from Dec. 1840 to Nov. 1841. H. Colburn, Londres, Reino Unido.

2. Betagh. W. 1728. Voyage Round the World, Being an Account of a Remarkable Enterprize, Begun in the Year 1719, Chiefly to Cruise on the Spaniards in the Great South Ocean. Relating the True Historical Facts of that Whole Affair: Testifyd by Many Imployd therein; and Confirmed by Authorities, from the Owners. T. Combes, J. Lacy and J. Clarke. Londres, Reino Unido. 266 p.

3. Burney, J. 1803-1816. A Chronological History of the Discoveries in the South Sea or Pacific Ocean. G \& W Nicol, Londres, Reino Unido. 4 vols.

4. Colnett, J. 1798. A Voyage to the South Atlantic and Round Cape Horn into the Pacific Ocean, for the 
Purpose of Extending the Spermaceti Whale Fisheries and other Objects of Commerce, by Ascertaining the Ports, Bays, Harbours, and Anchoring Births, in Certain Islands and Coasts in those Seas at which the Ships of the British Merchants might be Refitted. W. Bennett, Westminster, Londres, Reino Unido.

5. Comte de Gueydon, H.L. 1846. Copie d'un rapport addressé à M. leContre-Almiral Hamelin, par M. le Comte de Gueydon, Capitaine de Corvette, Commandant le brick 'Le Génie', sur sa relâche à l'île des Cocos en Novembre 1846. Traducido al inglés por T.R. Kelley, "Report on Cocos" y publicado en Pacific Discovery, Nov.-Dec. 1948: 8-14.

6. Coulter, J. 1847. Adventures on the West Coast of South America and the Interior of California. Longman, Brown, Green and Longmans Londres, Reino Unido. 2 vols,

7. Lièvre, D. 1893. Une ile déserte du Pacifique, L'ile des Cocos (Amerique). Bull. Soc. Geogr. Comer. Hávre: 233-258 (Traducido por Jorge y Maruja León (1945) "Una isla desierta en el Pacífico. La isla del Coco (América)". Publicado en: Lilia Ramos, Carlos Meléndez y Juvenal Valerio (comp.). 1962. Los viajes de Cockburn y Lièvre por Costa Rica. Edit. Costa Rica, San José, Costa Rica: 97-134.

8. Malaspina, A. 1885. Viaje político-científico alrededor del Mundo por las corbetas Descubierta y Atrevida al mando de los capitanes de navío D. Alejandro Malaspina y Don José de Bustamante y Guerra desde 1789 a 1794. Publicado con una introducción por Don Pedro de Novo y Colson. Imprenta de la Viuda e Hijos de Abienzo. Madrid.

9. Seymour, J. 1849. Notes on the island of Cocos, and two of the Galapagos. Journal of the Royal Geographical Society of London 19: 20-22.

10. Vancouver, G. 1801. A Voyage of Discovery to the North Pacific Ocean, and Round the World; In Which the Coast of North-west America has been Carefully Examined and Accurately Surveyed Undertaken by his Majesty's Command, Principally With a View to Ascertain the Existence of any Navigable Communication Between the North Pacific and North Atlantic Oceans, and Performed in the Years 1790, 1791, 1792, 1793, 1794 and 1795 in the Discovery Sloop of War, and Armed Tender Chatham, under the command of Capitan George Vancouver.. John Stockdale, Picadilly, Londres, Reino Unido. 6 vols. 